This preprint has been submitted to Freshwater Biology on the 24th of October 2019.

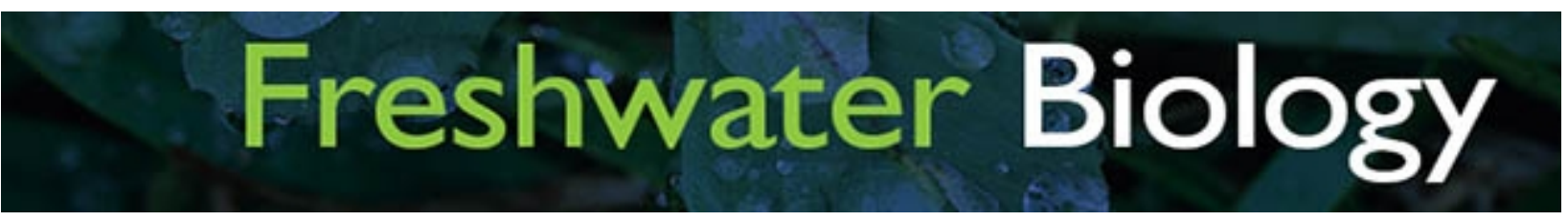

\title{
Macrophyte cover type and groundwater as the key drivers of the extremely high organic carbon concentration of soda pans
}

\begin{tabular}{|r|l|}
\hline Journal: & Freshwater Biology \\
\hline Manuscript ID & FWB-P-Jun-19-0305.R1 \\
\hline Manuscript Type: & Standard Paper \\
\hline Author: & n/a \\
\hline Complete List of Authors: & $\begin{array}{l}\text { Boros, Emil; Hungarian Academy of Sciences Centre for Ecological } \\
\text { Research, GINOP Sustainable Ecosystems Group, Danube Research } \\
\text { Institute, } \\
\text { V-Balogh, Katalin; Hungarian Academy of Sciences Centre for Ecological } \\
\text { Research, Balaton Limnological Institute, } \\
\text { Vörös, Lajos; Hungarian Academy of Sciences Centre for Ecological } \\
\text { Research, Balaton Limnological Institute } \\
\text { Csitári, Bianka; Eötvös Loránd Tudományegyetem, Department of } \\
\text { Microbiology; Uppsala University, Evolutionary Biology Centre, Limnology } \\
\text { Szekely, Anna ; Uppsala University, Evolutionary Biology Centre, } \\
\text { Limnology }\end{array}$ \\
\hline Keywords: & $\begin{array}{l}\text { Climate change < Applied Issues, Saline waters < Habitat, Chemical } \\
\text { environment < Level of Organisation, Higher plants < Taxonomic Group } \\
\text { / Assemblage, Greenhouse gases < Applied Issues, Ground water < } \\
\text { Habitat, Temporary pools < Habitat, Nutrient cycling < Process / } \\
\text { Approach / Methods }\end{array}$ \\
\hline & \\
\hline
\end{tabular}




\section{Macrophyte cover type and groundwater as the key drivers of the extremely high organic carbon concentration of soda pans}

$6 \quad{ }^{1}$ GINOP Sustainable Ecosystems Group, Danube Research Institute, MTA Centre for

7 Ecological Research, Danube Research Institute, Klebelsberg Kuno str. 3. P.O. Box 35, H-

88237 Tihany, Hungary

$9 \quad{ }^{2}$ Balaton Limnological Institute, MTA Centre for Ecological Research, Klebelsberg Kuno str.

10 3. P.O. Box 35 , H-8237 Tihany, Hungary

$11{ }^{3}$ Department of Microbiology, ELTE Eötvös Loránd University, Pázmány Péter stny. 1/c., H-

121117 Budapest, Hungary

$13{ }^{4}$ Evolutionary Biology Centre, Limnology, Uppsala University, Norbyvägen 18 D, SE-752

1436 Uppsala, Sweden

15

16 *Corresponding author; E-mail: drborose@gmail.com; boros.emil@okologia.mta.hu; 


\section{Summary}

1. Endorheic soda pans are among the aquatic systems that have the highest dissolved organic carbon (DOC) content on the planet with concentrations reaching values close to $1 \mathrm{~g} \mathrm{~L}^{-1}$. Considering the importance of inland waters in the global carbon cycle, the understanding of the drivers of such outstanding aquatic organic carbon pools is eminent. The soda pans of the Carpathian Basin present a wide variability of biotic and abiotic characteristics that provides an adequate system to assess the determinants of the extreme high DOC concentrations of soda pans. Here we demonstrate through a multisite comparison, a multiyear seasonal monitoring, and a laboratory experiment that the dissolved organic matter content of the highest DOC concentration soda pans is primarily of groundwater and emergent macrophyte origin.

2. More precisely, the multisite comparison of 14 soda pans revealed that the variation of colored dissolved organic matter (CDOM) content of the pans is partially explained by the CDOM content ( $21 \%$ of variation) and conductivity (14\%) of the local groundwater indicating significant role of allochthonous terrestrial DOC sources. However, $46 \%$ of the variation in CDOM content of the studied soda pans could be accounted for the dominant type of emergent macrophyte with Bolboshoenus maritimus dominated macrophyte cover leading to higher CDOM content than Phragmites australis.

3. In line with the results of the multisite comparison, we demonstrated by a decomposition experiment that both $B$. maritimus and $P$. australis have the potential to release substantial amount of organic matter into soda pans. However, the organic matter release of $B$. maritimus is much more intensive than that of $P$. australis leading to twice as high DOC and 3.5-times higher CDOM concentrations. In general, considering previous organic matter release studies we concluded that $P$. australis is a relatively low 
organic matter releaser emergent macrophyte, and therefore the species composition of emergent macrophytes has to be considered in autochthonous plant-derived DOM estimations.

4. Finally, the multi-year seasonal monitoring of two distinctive soda pans showed that the high organic matter concentrations of the pans depends not only on their intrinsic characteristics but also on interannual variability. More precisely, we demonstrated that the highest CDOM and DOC concentrations occurred in a colored (i.e., brown, low TSS) soda pan that had extensive (95\%) macrophyte cover dominated by B. maritimus in a period characterized by high $\mathrm{pH}$ due to low water levels, which were presumably the consequence of increased evaporation due to decreased precipitation and above average temperature. Considering the trends of climate change in Central-Europe (i.e., increased temperature and modified precipitation regimes), our results indicate that extremely high organic matter concentrations in soda pans might become more frequent in the near future.

59 Keywords: high pH, DOM, groundwater effect, emergent macrophytes, interannual variability 60 


\section{Introduction}

As inland waters receive, process, store and emit carbon in globally significant amounts (Cole et al., 2007), mapping active carbon in even the smallest aquatic systems is necessary for accurate global estimates of carbon cycling (Tranvik, Cole \& Prairie, 2018). Dissolved organic matter (DOM) is quantitatively the most significant pool of organic carbon in aquatic systems, which is either derived from terrestrial sources (i.e., allochthonous organic matter) or from biological material produced in situ by phytoplankton and macrophytes (i.e., autochthonous OM) (Williamson et al., 1999; Zhang et al., 2013). Terrestrial DOM can reach surface waters via surface inflow or runoff as well as via groundwater seepage (Wetzel, 2001; Grabs et al., 2012; Einarsdottir, Wallin \& Sobek, 2017). Therefore, the quantity and quality of DOM in inland waters is not only influenced by internal processes but also by the characteristics of the catchment area (e.g., vegetation, soil type, hydrology) (Wetzel, 2001; Kothawala et al., 2014; Sepp et al., 2019).

In inland waters DOM is considered to be dominated (15-80\%) by soluble humic substances (i.e., fluvic acids and humic acids). While fulvic acids are soluble at any $\mathrm{pH}$, the solubility of humic acids depends on $\mathrm{pH}$ with no dissolution at lower $\mathrm{pH}(\mathrm{pH}<2)$ and complete solubility at $\mathrm{pH} 13$ (Aiken et al., 1985). The $\mathrm{pH}$ of the water also affects the properties of the dissolved humic substances with more aromatic and aliphatic humic acids being dissolved at higher $\mathrm{pH}$ (Baglieri et al., 2014). Humic acids also contribute to the fluorescence signal of colored (chromophoric) DOM (CDOM) (Lapierre \& Frenette, 2009). Generally, allochthonous DOM is composed of more recalcitrant and highly colored humic substances than phytoplankton produced autochthonous DOM (Tranvik L. J., 1988; Wetzel, 2001). However, the refractory plant-derived CDOM can also originate from autochthonous sources such as littoral marshland 
86 considered to be recalcitrant due to their aromatic core, which is relatively resistant to microbial degradation (Kellerman et al., 2015). However, it has been shown that terrestrial carbon can be substantial contributor to microbial biomass (Guillemette, McCallister \& del Giorgio, 2015).

The global mean of dissolved organic carbon (DOC) concentration of lakes has been determined to be $5.02 \mathrm{mg} \mathrm{L}^{-1}$ (equivalent of $5.58 \mathrm{mg} \mathrm{L}^{-1}$ total organic carbon) and influenced by climatic factors (Chen et al., 2015) as well as watershed characteristics (Sobek et al., 2007). Although the globally most abundant shallow lakes (Downing et al., 2006; Verpoorter et al., 2014) have been shown to have double mean DOC concentration than deep lakes (6.56 and

$3.12 \mathrm{mg} \mathrm{L}^{-1}$, respectively) (Chen et al., 2015), the $90 \mathrm{mg} \mathrm{L}^{-1}$ mean DOC concentration of soda lakes can be considered as extreme even when compared to other highly productive aquatic systems such as eutrophic lakes, marshes or bogs (Fig. 1a). In addition, when looking at single measurements, soda pans are very likely the global record holders in DOC as occasionally DOC concentrations close to $1 \mathrm{~g} \mathrm{~L}^{-1}$ have been reported (Lake Nakuru: $980 \mathrm{mg} \mathrm{L}^{-1}$ (Jirsa et al., 2013); Sósér: $988 \mathrm{mg} \mathrm{L}^{-1}$ (Boros et al., 2016) (Fig. 1b).

Soda lakes and pans can be found on all continents except Antarctica and represent the most alkaline natural environments on Earth (Grant \& Sorokin, 2011). Soda lakes are formed in endorheic basins (i.e., limited drainage basins), where evaporation exceeds water outflow (Warren, 2006) and the levels of calcium $\left(\mathrm{Ca}^{2+}\right)$ and magnesium $\left(\mathrm{Mg}^{2+}\right)$ are low, while sodium $\left(\mathrm{Na}^{+}\right)$and carbonate species $\left(\mathrm{HCO}_{3}{ }^{-}+\mathrm{CO}_{3}{ }^{2-}\right)$ are high (Boros \& Kolpakova, 2018). Within Europe - to the best of our knowledge — soda pans are restricted to the Carpathian Basin and are found only in Austria, Hungary and Serbia. The climatic conditions of the region (i.e., continental with influence of both oceanic and Mediterranean climate) in combination with the shallowness of the pans cause high fluctuation in respect of water level and temperature. Water level fluctuation is of particular interest as it results in intermittent hydroperiods for many pans and affects the concentration of both organic and inorganic compounds. In the case of soda pans 
111 of the Carpathian basin, groundwater inflow typically exceeds the surface-related watershed 112 inflow and precipitation (Boros, Ecsedi \& Oláh, 2013). The analysis of 84 soda pans of the 113 region showed that many pans have extremely high DOC and CDOM concentrations (DOC: 114 median = 47; range: 20-664 $\mathrm{mg} \mathrm{L}^{-1}$; CDOM: median =310; range: $20-7,100 \mathrm{mg} \mathrm{Pt} \mathrm{L}{ }^{-1}$ ), which 115 indicates polyhumic $\left(\mathrm{CDOM}>90 \mathrm{mg} \mathrm{Pt} \mathrm{L}^{-1}\right)$ character (Boros et al., 2017). Furthermore, 116 extreme high DOC concentrations have also been recorded (Fig. 1b) (Boros et al., 2016). 117 Positive correlation between DOC and CDOM has been determined before for Carpathian soda 118 pans (V.-Balogh et al., 2009; Boros et al., 2013; 2016; 2017), while—despite the pH-dependent 119 solubility of humic substances - correlation between $\mathrm{pH}$ and DOC has not been demonstrated 120 (Boros et al., 2017).

121 Although high organic matter content is an inherent property of most soda lakes and pans, the 122 regulators of CDOM variation across soda pans are understudied and the causes of extremely 123 high DOC and CDOM concentrations such as those measured in the pans of the Carpathian 124 basin, are not properly understood. Therefore, in this study we aim to identify and test the main 125 sources of CDOM and DOC in polyhumic soda pans. Namely, we hypothesize that CDOM 126 concentration of polyhumic soda pans is positively affected by the allochthonous CDOM 127 concentrations of local groundwater and the extent of emergent macrophyte cover. 128 Furthermore, based on our earlier observations (Boros et al., 2017), we hypothesize that the 129 species composition of the autochthonous emergent macrophytes influences CDOM content 130 with cosmopolitan bulrush (Bolboshoenus maritimus (L.) Palla, Cyperaceae) dominated cover 131 leading to higher CDOM concentrations than common reed (Phragmites australis (Cav.) Trin. 132 ex Steud., Poaceae) dominated cover. To disentangle the effect of different macrophyte species 133 on CDOM and DOC concentrations, experimental assessment of the amount and ratio of 134 CDOM and DOC released from P. australis and B. maritimus was performed. Finally, to 135 identify the environmental conditions that lead to extreme DOC and CDOM values in soda 
136 pans, seasonal monitoring of a turbid and a colored polyhumic soda pans was conducted in two 137 separate years.

\section{Methods}

\section{$140 \quad$ Study sites and sampling}

141 The soda pans studied in this work are located in the central area of the Carpathian Basin, on

142 the interfluve area of the Danube and Tisza rivers (Fig. 2). The water budget of the soda pans

143 in this area is highly influenced by evaporation, precipitation and groundwater influx, while the

144 surface water inflow from the watershed is negligible as usually no major watercourse enters

145 these systems (Boros et al., 2013). The primary source of the high $\mathrm{Na}-\mathrm{HCO}_{3}-\mathrm{Cl}^{-}$content of the

146 soda pans of the region is the discharge from upwelling deep saline groundwater, which is 147 enhanced in the pans by evaporation (Simon et al., 2011). These soda pans can be categorized 148 into two groups based on their optical characteristics: the turbid type, where inorganic 149 suspended solids (ISS) are the main cause of turbidity or more precisely, the contribution of 150 ISS to light attenuation $\left(\mathrm{K}_{\mathrm{d}}\right)$ exceeds $50 \%$, and the colored (brown) type, where CDOM 151 contribution dominates $\mathrm{K}_{\mathrm{d}}(>50 \%)$ (Boros et al., 2013). Submerged and floating macrophytes 152 are sparse or absent from the open water areas of both turbid and colored pans. However, 153 marshland vegetation (Bolboschoeno-Phragmitetum) characterized primarily by varying ratios 154 of emergent macrophyte species $B$. maritimus and $P$. australis can be found on their shoreline. 155 This study comprises of three parts: a multisite comparison of soda pans, a decomposition 156 experiment and a seasonal analysis of a turbid and a colored soda pan.

157 In the multisite comparison 14 natural pans were sampled between April and September of 1582017 to assess the potential effect of groundwater and macrophytes on the organic matter 159 content. The pans were selected in order to cover a broad range in respect of turbidity, CDOM 160 and emergent macrophyte cover (Table 1). The coordinates of the location of the pans and the 
161 groundwater wells are listed in Table S1. The chemical type of the pans was determined

162 following the guidelines of Boros \& Kolpakova (2018). Two of the 14 pans were sampled in 163 the seasonal analysis: Zab-szék, a typical turbid pan (Table 1: Total Suspended Solids $($ TSS $)=$ $1641574 \mathrm{mg} \mathrm{L}^{-1}, \mathrm{CDOM}=364 \mathrm{mg} \mathrm{Pt} \mathrm{L}^{-1}$ ) and Sósér, a typical colored pan (TSS $83 \mathrm{mg} \mathrm{L}^{-1}$, $165 \mathrm{CDOM}=2088 \mathrm{mg} \mathrm{Pt} \mathrm{L}^{-1}$ ) (Boros et al., 2013; 2016; 2017). The seasonal assessment of these 166 two pans was performed in 2014 and 2017 with samplings approximately every other week 167 from January to December in 2014 and from March to November in 2017. On two occasions in 1682017 (11-Sep and 16-Oct) Zab-szék was completely dry, so no measurement was possible.

169 For all samplings water depth, conductivity and $\mathrm{pH}$ were determined on site in the open water 170 part of the pans using a centimeter-scale pole, and a WTW MultiLine P4 field instrument for $171 \mathrm{pH}$ and conductivity, respectively. Samples were collected and transported to the lab for 172 CDOM, DOC, TSS, and fluorescence excitation emission matrix spectroscopy (EEMS) 173 measurement. The groundwater was assessed by sampling dug wells (mean depth: 3-5 meters) 174 located within 500 meters from the shoreline of each pan (Table 1). According to topographic 175 maps, all of the sampled wells were established decades ago. For the macrophyte DOM release 176 experiment, aboveground fraction of stems and leaves of B. maritimus and $P$. australis 177 specimens in their early senescing stage were collected from Sósér soda pan in October 2012. 178 After collection, the plant samples were washed with pan water and kept in clean plastic bags 179 and brought to the laboratory.

181 Autochthonous emergent macrophyte cover assessment

182 The cover of open water and marshland vegetation (Bolboschoeno-Phragmitetum) of pans and 183 the classification based on $P$. australis and $B$. maritimus ratio were estimated with remote184 sensing databases extracted from Google Satellite raster data via OpenLayers plugin and 185 complemented with local field observations in 2017. The GIS mapping procedure and spatial 
186 calculations were carried out using ArcMap (Environmental Systems Research Institute 2013).

187 The proportion of emergent macrophyte cover (\%) was calculated based on the ratio of open 188 water and macrophyte cover (ha) and the characteristic macrophyte type of each soda pan was 189 determined by estimation of the ratio of the most common species ( $P$. australis and $B$. 190 maritimus). Pans with ratio of either species above 50\% were classified as either $P$. australis or 191 B. maritimus dominated (Table 1).

192

Experimental release of DOM from macrophytes

194 In the laboratory the plant material was cut into 20 -cm-long pieces, oven-dried to constant 195 weight at $35^{\circ} \mathrm{C}$ to avoid the destruction of the associated microbiome, and stored at room 196 temperature $\left(23^{\circ} \mathrm{C}\right)$ until the experiment. Fifty grams of oven-dried plant material (stems and 197 leaves) were placed into 5-liter bottles. The bottles were filled with 3.51 water $(\mathrm{pH}=8.4)$ 198 collected from the well near Kelemen-szék (Table 1, N: 46.8012; E: 19.1717). The well-water 199 was filtered with pre-combusted GF-5 acid-washed glass fiber filter (pore size $=0.4 \mu \mathrm{m}$ ). The 200 DOC and CDOM concentration of the well water were determined as for other samples. The 201 incubation was performed in three replicates in the dark at room temperature $\left(22-24{ }^{\circ} \mathrm{C}\right)$ for 29 202 days. The bottles were aerated with sterile-filtered atmospheric air and the dissolved oxygen 203 saturation ranged between $64 \%$ and $94 \%$ throughout the experiment. This aerobic treatment 204 was chosen, because an earlier study on $P$. australis showed that aerobic conditions are more 205 similar to the conditions in the field than anaerobic (V.-Balogh et al., 2006). On days 0, 1, 4, 7 , $20611,14,18,22,25$ and 29, $100 \mathrm{ml}$ of water were sampled from the bottles for analyses. The 207 water volume of the samples was always replaced, consequently the water volume remained 208 constant during the experiment. All glassware used for sample collection and analytical 209 processes was acid-washed and Milli-Q water rinsed. 
212 The water samples were filtered as for the DOM release experiment and the concentration of 213 colored dissolved organic matter $(\mathrm{CDOM})$ was expressed as $\mathrm{Pt}$ (platina) units $\left(\mathrm{mg} \mathrm{Pt} \mathrm{L} \mathrm{L}^{-1}\right)$ using 214 absorbance $(440 \mathrm{~nm})$ measurements with a Shimadzu UV 160A spectrophotometer (Cuthbert $215 \&$ del Giorgio, 1992). For DOC analyses, the filtered samples were acidified (to $\mathrm{pH} 2$ with $\mathrm{HCl}$ ) 216 and bubbled to remove dissolved inorganic carbon (DIC), and DOC concentration was 217 measured by thermal catalysis at $1050^{\circ} \mathrm{C}$ in an Elementar High TOC instrument equipped with 218 a platinum cartridge using synthetic air as carrier gas. The concentration of total suspended 219 solids (TSS) was measured by filtering water $(100-2000 \mathrm{ml})$ through pre-dried and pre-weighed 220 cellulose acetate filters (pore size $=0.45 \mu \mathrm{m}$ ) followed by oven-drying at $105^{\circ} \mathrm{C}$, and weighing 221 of dry filters using a CHYO YMC SM-200 analytical balance (accuracy $0.01 \mathrm{mg}$, precision $2220.02 \mathrm{mg})$.

Fluorescence Excitation Emission Matrix Spectroscopy

225 During the 2017 seasonal comparison of Sósér and Zab-szék samples were collected for 226 dissolved organic matter (DOM) characterization using fluorescence excitation-emission 227 matrix spectroscopy (EEMS). The samples were filtered through a $0.1-\mu \mathrm{m}$ pore size Millipore 228 Isopore Membrane Filters the same day and stored in combusted glassware at $4^{\circ} \mathrm{C}$ until 229 processing. EEMS profiles of the samples were determined as in Kothawala et al. (2014). 230 Briefly, excitation-emission matrices (EEM) were determined by measuring UV-visible 231 absorbance spectra using a Lambda 40 UV-visible spectrophotometer (Perkin Elmer, Waltham, 232 MA, United States) and measuring fluorescence emission using a fluorescence 233 spectrophotometer (SPEX FluoroMax-2, Horiba Jobin Yvon, Kyoto, Japan). Milli-Q water was 234 used as blank and its values were subtracted from the EEMs. Manufacturer supplied instrument 235 correction factors and the absorbance spectra were used for the correction of instrument and 
236 filter biases, respectively, while fluorescence intensity was calibrated to the Raman area of the 237 blank water.

\section{Data analyses}

240 To assess the effect of macrophytes on the CDOM content of the pans, the amount of non241 groundwater related $\mathrm{CDOM}$ (i.e., $\mathrm{CDOM}_{\text {diff }}$ ) was calculated by subtraction of the $\mathrm{CDOM}$ 242 concentration of the corresponding groundwater wells from the total CDOM concentration of 243 pans.

244 From the EEMS results three indicators have been calculated: fluorescence index (FI), freshness 245 index (FRESH), and humification index (HIX). The FI is used as an indicator of the source of 246 DOM: high FI $\sim 1.8$ indicates microbial and algal origin of DOM, while low FI $\sim 1.2$ suggests 247 terrestrial plant and soil derived DOM. The FRESH index is used as an estimator of how 248 recently the DOM has been produced ('freshness'). Finally, HIX indicates the humification of 249 DOM (i.e., amount of aromatic compounds) (Fellman, Hood \& Spencer, 2010).

250 In the multisite comparison, the variables influencing CDOM concentration in the pans were 251 evaluated by a linear model. The relevant variables for the linear model were selected from 252 those in Table 1 (except the distance of the well to the corresponding pan) by backward 253 selection using Akaike information criterion (AIC) estimator (Table S2). The linear model was 254 checked for multicollinearity and the variables that had the highest generalized variance 255 inflation factor (GVIF) were stepwise removed until reaching a model were the squared degrees 256 of freedom corrected GVIFs $\left(\left(\operatorname{GVIF}^{\wedge}(1 /(2 * D))^{\wedge} 2\right)\right.$ were less than five (Table S3). Differences 257 of measured variables and linear models were tested by Welch's $t$-tests and Analyses of 258 Variance (ANOVA), respectively. Correlations between parameters were evaluated with 259 Pearson's correlation analyses. To meet the assumptions of normality of residuals of parametric 260 tests and the requirements of linear correlations data was log-transformed when needed. 
261 Normality of residuals and variables was checked by Shapiro-Wilk test and visual analysis. In 262 the seasonal study the relationships over time of CDOM and DOC with TSS, water depth, $\mathrm{pH}$, 263 conductivity and the EEMS indexes were assessed on monthly averaged data using cross264 correlation analyses (Zab-szék in 2017 was excluded from these analyses due to repeated 265 complete droughts). Prior analyses the autocorrelation of the variables was removed by 266 differencing the series with a lag of one. The successful removal of autocorrelation was 267 confirmed by the Ljung-Box test. The Spearman correlation, non-linear curve fitting for 268 Michaelis-Menten kinetic function, Mann-Whitney, and Kruskal-Wallis tests used to analyze 269 the DOM release experiment were performed using OriginPro 9 (OriginLab, Northampton, 270 MA), while the EEMs data were analyzed with MATLAB. All other analyses were performed 271 using the R environment for statistical computing (R Core Team, 2015).

\section{Results}

274 Multisite comparison of the effect of groundwater and macrophytes

275 The identity, optical category (i.e., turbid or colored), chemical type (i.e., category based on 276 ionic composition, Boros \& Kolpakova, 2018), TSS as a measure of turbidity, emergent 277 macrophyte cover and type (i.e., Bolboschoeno or Phragmitetum dominated), and the shortest 278 distance between the sampled groundwater wells and the shoreline of the corresponding pans 279 are listed in Table 1. The CDOM concentration was almost always higher in the pan (median = $280287.6 \mathrm{mg} \mathrm{Pt} \mathrm{L}^{-1}$ ) than in the corresponding groundwater well (median $=112.2 \mathrm{mg} \mathrm{Pt} \mathrm{L}^{-1}$; paired 281 t-test $\log \mathrm{CDOM}: \mathrm{t}=3.912 ; \mathrm{p}=0.002$; Fig $3 \mathrm{a})$. The $\mathrm{pH}$ of each pan $($ median $=9.28)$ was also 282 significantly higher than the $\mathrm{pH}$ of the corresponding well (median $=8.60$; paired $\mathrm{t}$-test $\mathrm{t}=$ 283 3.896, $\mathrm{p}=0.002$ ), while the difference between the conductivity of the pans and the 284 corresponding wells was not significant $\left(\right.$ median $_{\text {pans }}=3.0 \mathrm{~g} \mathrm{~L}^{-1}$; median $_{\text {wells }}=1.8 \mathrm{~g} \mathrm{~L}^{-1}$; paired $\mathrm{t}$-test $\mathrm{t}=2.086, \mathrm{p}=0.057)($ Table 1$)$. 
286 In the pans dominated by B. maritimus CDOM was slightly but not significantly higher than in 287 those dominated by $P$. australis $\left(\operatorname{median}_{\text {B.maritimus }}=1059 \mathrm{mg} \mathrm{Pt} \mathrm{L}{ }^{-1} ; \operatorname{median}_{\text {P.australis }}=253 \mathrm{mg}\right.$ $288 P \mathrm{Pt} \mathrm{L}^{-1}$; t-test $\mathrm{t}=2.269, \mathrm{p}=0.053$; Fig. $3 \mathrm{c}$ ). In the case of the soda pan that completely lacked 289 macrophyte cover the CDOM concentration of the pan was very similar to the CDOM of the 290 groundwater well (Table 1: Unnamed pan). For both the pans dominated by B. maritimus and 291 P. australis CDOM concentration of the soda pans showed positive relationship to the CDOM 292 concentration of the wells (Fig. 3c), although this correlation was only significant in the case 293 P. australis dominated pans (Pearson's B. maritimus: $\mathrm{r}=0.643 ; \mathrm{p}=0.168 ;$ P. australis: $\mathrm{r}=0.803$; $294 \mathrm{p}=0.029)$. For the pans with $B$. maritimus dominance the non-groundwater related $\mathrm{CDOM}_{\text {diff }}$ 295 (median=653.5 $\mathrm{mg} \mathrm{Pt} \mathrm{L}^{-1}$ ) was also higher $(\mathrm{t}$-test $\mathrm{t}=2.603, \mathrm{p}=0.044)$ than for those dominated 296 by P. australis (median=114.94 $\mathrm{mg} \mathrm{Pt} \mathrm{L}^{-1}$; Fig. 3b).

297 For the linear model, backward variable selection retained all assessed variables but the water 298 depth and the optical type (Table S2), while the chemical type and the $\mathrm{pH}$ of the pans were 299 removed to avoid collinearity (Table S3). The linear model using CDOM and pH of the wells, 300 conductivity of both pans and wells, TSS of then pans, and emergent macrophyte cover and 301 type (Table 1) explained $92.4 \%$ of the variation of CDOM content of the pans, and the ANOVA 302 (Fig. 3d, Table S4) revealed that the macrophyte type of the pans significantly explained 45.8\% 303 of the variation ( $p=0.004)$, while the CDOM content and the conductivity of the groundwater 304 wells significantly explained $21.2 \%(p=0.006)$ and $13.9 \%(p=0.012)$, respectively. The $9.8 \%$ 305 variance explained by the conductivity of the pans, and the $1.2 \%$ explained by the extent of the 306 emergent macrophyte cover was not significant $(p=0.052$ and $p=0.416$, respectively), while 307 the $\mathrm{pH}$ of the pans and TSS explained less than $1 \%$ and was not significant $(\mathrm{p}>0.1)$. 308 309 Experimental release of DOM from macrophytes 
310 After the 29-days-long incubation of the DOM release experiment, the plant material of $P$. 311 australis lost $7.33 \pm 0.15 \%(3.66 \pm 0.075$ g) dry mass, while B. maritimus lost $10.28 \pm 2.79 \%$ $312(5.14 \pm 1.40 \mathrm{~g})$. The initial CDOM concentration in the experimental bottles was $39.23 \pm 2.22 \mathrm{mg}$ $313 \mathrm{Pt} \mathrm{L}{ }^{-1}$ and by the end of the experiment it increased in average to $1190 \mathrm{mg} \mathrm{Pt} \mathrm{L}^{-1}$ and to 3900 $314 \mathrm{mg} \mathrm{Pt} \mathrm{L}^{-1}$ for P. australis and B. maritimus, respectively. The total CDOM release from the 315 degraded plant material was $1136 \mathrm{mg} \mathrm{Pt} \mathrm{g}^{-1}$ dry weight loss and $2675 \mathrm{mg} \mathrm{Pt} \mathrm{g}^{-1}$ dry weight loss 316 for P. australis and B. maritimus respectively. According to the Michaelis-Menten kinetics, at 317 the end of the experiment the CDOM concentration was $90.9 \%$ and $86.7 \%$ of the possible 318 maximum $\left(\mathrm{V}_{\max }\right)$ for P. australis and B. maritimus, respectively (Fig. 4a).

319 The initial DOC concentration was $13.40 \pm 0.099 \mathrm{mg} \mathrm{L}^{-1}$ and by the end of the experiment 320 increased in average to $82 \mathrm{mg} \mathrm{L}^{-1}$ and to $183 \mathrm{mg} \mathrm{L}^{-1}$ for P. australis and B. maritimus 321 incubations, respectively. The total DOC released from the degraded plant material was $78 \mathrm{mg}$ $322 \mathrm{~g}^{-1}$ dry weight loss and $125 \mathrm{mg} \mathrm{g}^{-1}$ dry weight loss for P. australis and B. maritimus, 323 respectively. According to the Michaelis-Menten kinetics, at the end of the experiment the DOC 324 concentration was $100.9 \%$ and $96.8 \%$ of the possible maximum $\left(\mathrm{V}_{\max }\right)$ for P. australis and B. 325 maritimus, respectively (Fig. 4b). The CDOM/DOC ratio increased linearly with significant 326 parameters from 9 to 14.5 and from 16 to 21 for $P$. australis and B. maritimus, respectively 327 (Fig. 4c).

\section{Seasonal comparison of a turbid and a colored pan}

330 As expected, the turbid Zab-szék had substantially higher turbidity than the colored Sósér soda 331 pan throughout most of the study period except for two timepoints in summer 2014 (Table 2, 332 Fig 5a). Water depth showed high variation in both pans (Fig 5b), although it was slightly higher 333 in Sósér than in Zab-szék (Table 2). Water depth changes also indicated that the hydrology of 334 the two studied years also followed different patterns as for both pans the beginning of the year 
335 in 2014 was characterized by low water depth, which increased from September-October until 336 the end of the year. Meanwhile, in 2017 both pans had higher water levels at the beginning of 337 the year until August, when the water levels decreased and remained low until the end of the 338 study period (Fig 5b). Throughout the two years the pans differed in respect of $\mathrm{pH}$ but not 339 conductivity (Table 2, Fig 5c,d). Both CDOM and DOC were higher in Sósér pan than in Zab340 szék (Table 2, Fig 5e,f). The concentration of CDOM and DOC also differed between the two 341 years with higher values for both pans in 2014 than in 2017 (Table 2, Fig 5e,f) More precisely, 342 the highest CDOM and DOC levels were all measured in Sósér in 2014 between January and 343 August, which corresponded to the lowest water level period of the given year (Fig. 5b). In this 344 period the mean concentration of CDOM was $6,649 \mathrm{mg} \mathrm{Pt} \mathrm{L}^{-1}$ and $563 \mathrm{mg} \mathrm{L}^{-1}$ for DOC, while 345 for the rest of the year was $1,294 \mathrm{mg} \mathrm{Pt} \mathrm{L}^{-1}$ and $111 \mathrm{mg} \mathrm{L}^{-1}$ for CDOM and DOC, respectively. 346 The two pans also differed in respect of the indicators calculated from the EEMS (Fig 6). Sósér 347 had higher humification index (HIX) throughout the study period, while the freshness index 348 (FRESH) was higher at every timepoint in Zab-szék than in Sósér (Table 2, Fig 6b,c). In 349 addition, both pans had generally higher FRESH values in summer and Zab-szék had a 350 prominent FRESH peak in the beginning of summer (29-May) (Fig 6b). The fluorescence index 351 (FI) did not differ between the two pans (Table 2), although it showed much higher variation in 352 Zab-szék with prominent peaks in summer and autumn (Fig. 6a). For both pans the mean FI 353 index was close to the value expected for DOM of terrestrial and soil origin (Sósér: $\mathrm{FI}_{\text {median }}=$ 354 1.235; Zab-szék: FI median $_{1.236) .}$

355 The cross-correlation analyses revealed that both CDOM and DOC were most strongly 356 correlated with TSS, depth, $\mathrm{pH}$ and conductivity measured at the same time $(\mathrm{lag}=0)$ except for 357 DOC concentration in Zab-szék in 2014 and its correlation with TSS, depth and pH (Table S5). 358 In the case of Sósér, the lag $=0$ correlations between DOC concentration and TSS, depth, pH 359 and conductivity were always significant (positive correlation with TSS, $\mathrm{pH}$ and conductivity, 
360 and negative with mean)(Table 3). In Zab-szék DOC showed significant (positive) correlation 361 at lag $=0$ only with depth and conductivity (Table 3 ), while for TSS only values measured 2 362 months earlier $(\mathrm{lag}=2)$ showed significant positive correlation with actual DOC, and for $\mathrm{pH}$ 363 only values measured 5 months later $(\operatorname{lag}=-5)$ were significantly correlated with actual DOC 364 (Table S5). The CDOM concentration did not significantly correlate with the TSS of the pans, 365 while mean depth, $\mathrm{pH}$ and conductivity significantly correlated with CDOM in all cases but $\mathrm{pH}$ 366 in Sósér in 2017 and conductivity in Zab-szék in 2014. Interestingly, the sign of the correlations 367 with CDOM depended on the pan: in Sósér CDOM positively correlated with $\mathrm{pH}$ and 368 conductivity, and negatively with depth, while in Zab-szék CDOM negatively correlated with $369 \mathrm{pH}$ and conductivity, and positively with depth. In the case of the EEMS indexes significant 370 correlations were only found for DOC in Sósér: FRESH showed significant positive correlation 371 with DOC measured the same time and HIX showed significant negative correlation with DOC 372 measured three months earlier (Table 3, Table S5). In the case of HIX the highest (non373 significant) correlations with CDOM in both pans were also detected with CDOM measured 374 three months earlier (Table S5).

\section{Discussion}

377 The results of our study indicate - as we hypothesized - that the CDOM variation in the soda 378 pans of the Carpathian basin is highly influenced by groundwater and the dominant species of 379 the macrophyte cover but - opposite to our hypothesis - it is not significantly driven by the 380 extent of the cover. Furthermore, we demonstrated that the variation of DOC and CDOM 381 concentrations of these pans is related to the variations in $\mathrm{pH}$, conductivity and water depths, 382 and it is presumably influenced by yearly variations in hydroperiods and intrinsic pan properties 383 such as turbidity. 


\section{Groundwater as allochthonous source of CDOM}

386 Plant-derived colored DOM in inland waters originates either from macrophytes or from 387 terrestrial vegetation of the watershed via surface or groundwater inflow (i.e., allochthonous 388 source) (V.-Balogh et al., 1998; Wetzel, 2001; Lapierre \& Frenette, 2009; Einarsdottir et al., 389 2017). As no watercourse enters the endorheic intermittent soda pans studied here, the role of 390 surface inflow in their water budget is negligible (Boros et al., 2013), and therefore their plant391 derived DOM content is expected to be primarily derived from macrophytes and groundwater 392 inflow. The multisite comparison of polyhumic soda pans demonstrated that the CDOM 393 concentration of pans is related to the CDOM concentration of groundwater (Fig. 3). 394 Groundwaters store and release carbon to surface waters in amounts that are meaningful for 395 global budgets (Downing \& Striegl, 2018) and import of terrestrial carbon into lakes via 396 groundwater seepage has been shown to be substantial even in the case of boreal lakes with 397 hydrology dominated by surface water inflow (Einarsdottir et al., 2017). In areas of lower relief, 398 shallow basins can be the focus of local discharge and evaporation from regionally extensive 399 groundwater systems (Deocampo \& Jones, 2014) and modern continental evaporates like soda 400 lakes and pans typically accumulate within groundwater discharge (Warren, 2006). Such 401 groundwater driven hydrological processes have been also identified behind the formation of 402 soda pans of the Danube-Tisza Interfluve (Mádl-Szőnyi \& Tóth, 2009; Simon et al., 2011). The 403 groundwaters analyzed in this study had relatively high pH (median: 8.60, range: 7.02-9.56, 404 Table 1.), which - considering the $\mathrm{pH}$-dependent dissolution of humic substances — is very 405 likely one of the reasons of their high CDOM content. Considering the high CDOM content of 406 local groundwaters and the importance of groundwater in the hydrology of the soda pans of the 407 region (Simon et al., 2011), it is not surprising that groundwater CDOM explained a substantial 408 part of the variation of the CDOM concentration of the studied soda pans. Finally, the mean FI 409 indexes measured by EEMS in the seasonal monitoring were close to 1.2, which is considered 
410 to indicate plant and soil derived organic matter (Fellman et al., 2010) further enforcing the 411 partly terrestrial origin of the DOM of the pans.

\section{Autochthonous emergent macrophyte cover type influences CDOM content}

414 However, the relationship between CDOM content of the pans and the corresponding 415 groundwaters depended on the dominant type of emergent macrophytes of the pans with pans 416 dominated by B. maritimus having higher CDOM content than those dominated by P. australis 417 (Fig. 3). While in the case of lakes macrophyte derived DOC is considered to contribute only 418 to $1-20 \%$ of the total DOC, for wetlands and small lakes macrophytes role in the carbon budget 419 can be substantial (Sobek et al., 2006; Reitsema, Meire \& Schoelynck, 2018). However, in our 420 linear model macrophyte species dominance was much more important in explaining the 421 variance in CDOM content among the studied pans than the extent of the macrophyte cover 422 (45.8 vs $1.2 \%$ of variance explained, respectively). A possible explanation to this seemingly 423 surprising result is that in the multisite comparison we focused on CDOM and not total DOC, 424 which depends both on total DOC and the color of DOM. It has been shown that qualitatively 425 macrophyte-derived DOM depends on the type of macrophyte (Qu et al., 2013). Accordingly, 426 it is reasonable that in the given dataset the dominant species of macrophytes is more important 427 in explaining the pans' CDOM content than the extent of emergent macrophyte cover.

428 The importance of the type of vegetation was corroborated by the results of the DOM release 429 experiment, which also showed that more than triple CDOM and more than double the amount 430 of DOC is released from B. maritimus than from P. australis. While DOM release from $P$. 431 australis has been studied before, to the best of our knowledge this is the first report for $B$. 432 maritimus. The DOC release results for $P$. australis presented here $\left(82 \mathrm{mg} \mathrm{L}^{-1}\right)$ compare well 433 to those from a previous experiment conducted under similar conditions $\left(75 \mathrm{mg} \mathrm{L}^{-1}\right)(\mathrm{V} .-\mathrm{Balogh}$ 434 et al., 2006) indicating high reproducibility of our experiment. When compared to other 
435 emergent macrophytes $P$. australis also released less DOC than crofton weed (Eupatorium 436 adenophorum (Spreng.) R.M.King \& H.Rob., Asteraceae), water oats (Zizania latifolia 437 (Griseb.) Turcz., Poaceae), oriental pepper (Polygonum orientale (L.) Spach., Polygonaceae) 438 (Qu et al., 2013), or seepweed (Suaeda salsa (L.) Pall., Amaranthaceae) (Qi, Xue \& Wang, 439 2017). All these indicates that common reed (P. australis) is a relatively low DOC releasing 440 emergent macrophyte and accordingly, it is essential to consider the composition of emergent 441 macrophytes when assessing macrophyte impact on the carbon balance of aquatic systems.

442 The total release of DOC within the time of the experiment reached values close to the 443 maximum expected for both species (Fig. 4b), while the total CDOM release did not reach the 444 maximum expected for either of the species (Fig. 4a). This contrasting dynamic between $445 \mathrm{CDOM}$ and DOC resulted in continuously increasing ratio of CDOM and DOC (Fig. 4c). To 446 better mimic natural conditions our experiment was not conducted under sterile conditions and 447 oxygen for aerobic microbial degradation was provided by aeration, therefore, the increase in 448 the ratio of CDOM suggest microbial degradation of the labile carbon fraction and concomitant 449 accumulation of recalcitrant colored DOM. The importance of microbial degradation in DOC 450 release was demonstrated by the experiment of Qi, Xue \& Wang (2017) were the amount of 451 DOC released from $P$. australis under sterile conditions was nine times higher than the quantity 452 released without inhibition of microbial degradation.

453 Considering the implications of our experiment to natural conditions, we have to emphasize 454 that the $\mathrm{pH}$ of the water used in the experiment was lower $(\mathrm{pH} 8.40)$ than the $\mathrm{pH}$ of almost all 455 pans analyzed in the multisite comparison (Table 1; $\mathrm{pH}$ 9.36). In a decomposition experiment 456 increasing $\mathrm{pH}$ has been shown to correlate with increasing dry mass loss from macrophyte litter 457 (Krachler et al., 2010), which together with the pH dependent dissolution of humic substances 458 suggests even higher release of DOC and CDOM from macrophytes in the pans than in our 459 experiment. However, the CDOM/DOC ratio at the end of the experiment was 14 times higher 
460 for P. australis and 21 times higher for B. maritimus than the average ratio of 6.6 measured for 46184 soda pans of the Carpathian Basin (Boros et al., 2017). A possible explanation for higher 462 proportion of colorless organic matter in natural habitats is photochemical degradation of 463 CDOM, which has been demonstrated to be a significant contributor to organic carbon 464 mineralization in boreal lakes, and which is expected to be particularly important in shallow 465 high DOC lakes (Koehler et al., 2014). In summary, it is likely that the autochthonous plant466 derived DOM of soda pans depends on the species composition of the emergent macrophytes 467 and the interplay of microbial and photochemical degradation. 468 469 Potential drivers of the seasonal variation of CDOM and DOC

470 The seasonal comparison of two soda pans with significant differences in respect of optical 471 characteristics (i.e., colored Sósér and turbid Zab-szék) is reasonable particularly considering 472 the potential importance of photochemical reactions. Sósér and Zab-szék also differ in respect 473 of emergent macrophyte cover ( $95 \%$ and $16 \%$, respectively) and dominant macrophyte species 474 (B. maritimus and P. phragmites, respectively) (Table 1). Although both pans had much higher 475 CDOM and DOC concentration than those characteristic for other aquatic systems (Fig. 1a), in 476 the case of the colored pan the concentration of both CDOM and DOC was extremely high. 477 Based on the findings of the multisite comparison and DOC release experiment the extensive 478 B. maritimus dominated macrophyte cover supposedly contributed to the extreme CDOM and 479 DOC concentrations of Sósér. Meanwhile, compared to Sósér Zab-szék had slightly higher pH, 480 lower water depth and consequently intermittent hydrology with several droughts in 2017 . The 481 two pans also differed based on the qualitative EEMS analyses of DOM. The higher HIX index 482 of Sósér suggests higher ratio of plant-derived recalcitrant DOM, while the higher FRESH 483 index of Zab-szék suggests greater ratio of freshly produced autochthonous DOM (Fig 6). 
484 In addition, substantial differences in the hydrology and overall CDOM and DOC 485 concentrations of the two years monitored were also observed. A potential explanation of the 486 contrasting patterns of hydrology of the two years might be in the differences in temperature 487 and precipitation regimes of the study years and the preceding periods. Although weather 488 analyses are beyond the scope of this study, regional records show that between July 2013 and 489 June 2014 the weather was dryer and much warmer than usual. Specifically, the precipitation 490 between July and December of 2013 was only $75 \%$ of the monthly mean measured for the 491 region between 1981 and 2010 and in the following period (Jan-Jun 2014) the temperature was $4922.3^{\circ} \mathrm{C}$ higher than the monthly mean (Fig. S1). Meanwhile, for the same period in 2016-2017 493 both temperature and precipitation were close to average (Fig. S1). Considering the importance 494 of groundwater in the hydrology of the soda pans in this region (Mádl-Szőnyi \& Tóth, 2009), 495 the combination of decreased precipitation followed by high temperature in 2013 and 2014 496 might have caused increased evapotranspiration from soils, leading to decreased groundwater 497 levels, and consequently less groundwater influx to the pans, which explains the lower water 498 levels measured for both pans in the beginning of 2014 compared to 2017. Similarly, the 499 opposite water level trends in autumn (i.e., increase in 2014 and decrease in 2017; Fig. 5b) 500 could be explained with precipitation and temperature anomalies such as the unusually high 501 precipitations in the second half of 2014 (156\% of average precipitation; Fig. S1).

502 In Sósér the lower water level period of 2014 coincided with the highest DOC and CDOM 503 concentrations measured (Fig. 5e,f). In this period the mean DOC concentration of the pan was $504563 \mathrm{mg} \mathrm{L}^{-1}$, which is more than an order of magnitude higher than the average of wetlands (Fig. 505 1a) and remarkable even among soda lakes and pans (e.g. Jirsa et al., 2013; Boros et al., 2017). 506 Both the CDOM and DOC concentrations of Sósér were negatively correlated with water depth 507 throughout the study period (Table 3), which suggests that evaporation driven concentration 508 contributed to the extremely high CDOM and DOC levels measured here. This is supported by 
509 the positive correlation of CDOM and DOC to conductivity and $\mathrm{pH}$ as both are also expected 510 to increase with decreasing water levels due to the concentration of inorganic ions. Furthermore, 511 considering the $\mathrm{pH}$ dependence of the dry matter loss from macrophyte litter (Krachler et al., 512 2010), the higher $\mathrm{pH}$ of the period could have further aggravated the OM release from the dense 513 B. maritimus dominated macrophyte cover of Sósér contributing to the measured record high 514 DOC levels. Turbidity positively correlated with DOC suggesting that in this otherwise low 515 turbidity pan (TSS in Zab-szék was almost 20 times higher than in Sósér; Fig. 5a), where 516 organic carbon is the main cause of turbidity opposite to clay minerals, which are typical for 517 turbid type pans such as Zab-szék (Boros et al., 2013).

518 On the other hand, in Zab-szék the correlation between depth and both CDOM and DOC was 519 positive (Table 3) suggesting that in this groundwater fed pan, possible groundwater itself was 520 the primary source of CDOM and DOC. This explanation was also supported by the results of 521 the multisite comparison, where for this pan - exceptionally among the other studied pans522 the CDOM content of the nearby groundwater well was almost double of the CDOM content 523 of the pan (Table 1). Interestingly, in this pan CDOM and DOC correlated differently with $\mathrm{pH}$ 524 and conductivity: for CDOM the correlation was negative, while for DOC it was positive. 525 Considering the lower $\mathrm{pH}$ and conductivity of the nearby groundwater well, their negative 526 correlations with CDOM agree with its groundwater origin theory. However, the positive 527 correlations of DOC and conductivity are seemingly contradictory to this theory. As DOC 528 measures both labile and recalcitrant organic carbon, while CDOM reflects more recalcitrant 529 organic carbon, a potential explanation to the increasing DOC content at higher conductivity 530 could be the presence of salinity dependent biodegradation inhibition as salinity is one of the 531 strongest microbial inhibitors (Székely et al. 2013). However, it is also possible that the higher

532 DOC but lower CDOM concentrations at high conductivity reflect non-humic freshly produced 533 autochthonous DOM, which together with the lesser macrophyte coverage and the $P$. 
534 phragmites dominance suggests that the influence of phytoplankton and microbial communities 535 on the DOM of this pan could also be prominent. This explanation is enforced by the contrasting 536 microbial community of the two pans described by Szabó et al. (2017) and by the peaks of FI 537 index in Zab-szék (Fig 6a), which are potential indicators of phytoplankton and microbial 538 blooms suggesting greater importance of microbial processes in the carbon dynamics of this 539 pan than in Sósér.

540 In a broader perspective, our results demonstrate that in the case of endorheic water bodies541 particularly those lacking surface inflow - groundwater can be an important source of organic 542 carbon that should be accounted for in carbon budget calculations. We also showed that 543 emergent macrophytes are essential sources of recalcitrant organic carbon. Although when 544 estimating macrophyte effect, species composition has to be also considered since common 545 reed (P. australis), one of the most common emergent macrophytes on a global scale has 546 relatively low organic carbon release compared to other species such as the cosmopolitan 547 bulrush (B. maritimus), for which this study comprises the first report of experimental 548 decomposition measurements. Finally, we demonstrated that the record high DOC values (0.5-1 $549 \mathrm{~g} \mathrm{~L}^{-1}$ ) measured in the soda pans of the Carpathian basin are the result of the interplay of 550 intrinsic soda pan characteristics such as B. maritimus dominated macrophyte cover and most 551 importantly persistent low water levels that occur in consequence of weather anomalies. More 552 precisely, we showed that high organic carbon content periods follow extreme warm and dry 553 seasons. Considering that such weather patterns might increase in frequency in the near future 554 due to the ongoing climate change, soda pans could become increasingly important hotspots of 555 terrestrial carbon processing urging further studies exploring the carbon biogeochemistry of 556 soda lakes. 
559 The data collection, assessment and study was founded by European-financed Hungarian 560 Economic Development and Innovation Operative Programme (GINOP-2.3.2-15-2016-00019) 561 at the GINOP Sustainable Ecosystems Group of Hungarian Academy of Sciences (MTA) 562 Centre for Ecological Research, as well as by the Swedish Research Council Formas through a 563 grant to A.J.S. and the Nation's Young Talent Scholarship from the Ministry of Human 564 Capacities (NTP-NFTÖ-18-B-0217) to B.C. We deeply thank to Tamás Sápi, Csaba Pigniczki 565 for assistance in the field at the Kiskunság National Park (Hungary) and we are also grateful to 566 Karólína Einarsdóttir and Marloes Groeneveld for their help with sample and data processing. 567

\section{Data Availability Statement}

569 The seasonal monitoring data and fluorescence spectra used for the EEMS analyses are 570 available on the online repository at: $\underline{\mathrm{http}} / / / \mathrm{urn} . \mathrm{kb} . \mathrm{se} / \mathrm{resolve}$ ?urn=urn:nbn:se:uu:diva-385197. 571

\section{Conflict of Interest Statement}

573 We declare that there is no actual or potential conflict of interest.

\section{References}

576 Aiken, G.R., McKnight, D.M., Wershaw, R.L., and MacCarthy P. (1985). Humic Substances in Soil, Sediments, and Water. In: Humic substances in soil, sediment and water: 579 McKnight), pp. 1-9. John Wiley \& Sons, Inc.

580 Baglieri A., Vindrola D., Gennari M. \& Negre M. (2014). Chemical and spectroscopic 581 characterization of insoluble and soluble humic acid fractions at different $\mathrm{pH}$ values. $582 \quad$ Chemical and Biological Technologies in Agriculture 1, 1-11.

583 Boros E., Ecsedi Z. \& Oláh J. (2013). Ecology and management of soda pans in the 
584 Carpathian basin. (Ed. Hortobágy Environmental Association), Balmazújváros.

585 Boros E., Pigniczki C., Sápi T., V.-Balogh K., Vörös L. \& Somogyi B. (2016). Waterbird586 Mediated Productivity of Two Soda Pans in the Carpathian Basin in Central Europe. $587 \quad$ Waterbirds 39, 388-401.

588 Boros E., V.-Balogh K., Vörös L. \& Horváth Z. (2017). Multiple extreme environmental 589 conditions of intermittent soda pans in the Carpathian Basin (Central Europe). $590 \quad$ Limnologica 62, 38-46.

591 Boros E. \& Kolpakova M. (2018). A review of the defining chemical properties of soda lakes 592 and pans : An assessment on a large geographic scale of Eurasian inland saline surface 593 waters. 1-20. PLoS ONE 13(8): e0202205. https://doi.org/10.1371/journal.

594 Chen M., Zeng G., Zhang J., Xu P., Chen A. \& Lu L. (2015). Global Landscape of Total 595 Organic Carbon, Nitrogen and Phosphorus in Lake Water. Scientific Reports 5, 1-7. 596 Cole J.J., Prairie Y.T., Caraco N.F., McDowell W.H., Tranvik L.J., Striegl R.G., et al. (2007). 597 Plumbing the Global Carbon Cycle: Integrating Inland Waters into the Terrestrial Carbon $598 \quad$ Budget. Ecosystems 10, 172-185.

599 Cuthbert I.D. \& del Giorgio P. (1992). Toward a standard method of measuring color in $600 \quad$ freshwater. Limnology and Oceanography 37, 1319-1326.

601 Deocampo D.M. \& Jones B.F. (2014). Geochemistry of Saline Lakes Geochemistry of Saline 602 Lakes. In: Treatise on Geochemistry, 2nd edn. pp. 437-469. Elsevier Ltd.

603 Downing, J. A., Prairie, Y. T., Cole, J. J., Duarte, C. M., Tranvik, L. J., Striegl, R. G., ... 604 Middelburg, J. J. (2006). The global abundance and size distribution of lakes, ponds, and 605 impoundments. Limnology and Oceanography, 51, 2388-2397.

606 Downing J.A. \& Striegl R.G. (2018). Size, age, renewal, and discharge of groundwater 607 carbon. Inland Waters 8, 122-127.

608 Einarsdottir K., Wallin M.B. \& Sobek S. (2017). High terrestrial carbon load via groundwater 
609

610

611

612

613

614

615

616

617

618

619

620

621

622

623

624

625

626

627

628

629

630

631

632

633

to a boreal lake dominated by surface water inflow. Journal of Geophysical Research: Biogeosciences 122, 15-29.

Fellman J.B., Hood E. \& Spencer R.G.M. (2010). Fluorescence spectroscopy opens new windows into dissolved organic matter dynamics in freshwater ecosystems: A review. Limnology and Oceanography 55, 2452-2462.

Grabs T., Bishop K., Laudon H., Lyon S.W. \& Seibert J. (2012). Riparian zone hydrology and soil water total organic carbon (TOC): Implications for spatial variability and upscaling of lateral riparian TOC exports. Biogeosciences 9, 3901-3916.

Grant W. \& Sorokin D.Y. (2011). Distribution and Diversity of Soda Lake Alkaliphiles. In: Extremophiles Handbook. (Eds K. Horikoshi, G. Antranikian, A.T. Bull, F.T. Robb \& K.O. Stetter), pp. 27-54.

Guillemette F., McCallister S.L. \& del Giorgio P.A. (2015). Selective consumption and metabolic allocation of terrestrial and algal carbon determine allochthony in lakes. The ISME journal, 1-10.

Jirsa F., Gruber M., Stojanovic A., Omondi S.O., Mader D., Körner W., et al. (2013). Major and trace element geochemistry of Lake Bogoria and Lake Nakuru, Kenya, during extreme draught. Chemie der Erde 73, 275-282.

Kayranli B., Scholz M., Mustafa A. \& Hedmark Å. (2010). Carbon storage and fluxes within freshwater wetlands: A critical review. Wetlands 30, 111-124.

Kellerman A.M., Kothawala D.N., Dittmar T. \& Tranvik L.J. (2015). Persistence of dissolved organic matter in lakes related to its molecular characteristics. Nature Geoscience $\mathbf{8}$, $454-457$.

Koehler B., Landelius T., Weyhenmeyer G.A., Machida N. \& Tranvik L.J. (2014). Sunlightinduced carbon dioxide emissions from inland waters Birgit. Global Biogeochemical Cycles, 696-711. 
634 Kothawala D.N., Stedmon C.A., Müller R.A., Weyhenmeyer G.A., Köhler S.J. \& Tranvik L.J. 635 (2014). Controls of dissolved organic matter quality: evidence from a large-scale boreal 636 lake survey. Global change biology 20, 1101-14.

637 Krachler R.F., Krachler R., Stojanovic A., Wielander B. \& Herzig A. (2010). Effects of pH on 638 aquatic biodegradation processes. Biogeosciences Discussions 6, 491-514.

639 Lapierre J.F. \& Frenette J.J. (2009). Effects of macrophytes and terrestrial inputs on 640 fluorescent dissolved organic matter in a large river system. Aquatic Sciences 71, 15-24.

641 Mádl-Szőnyi J. \& Tóth J. (2009). A hydrogeological type section for the Duna-Tisza 642 Interfluve, Hungary. 961-980.

643 Qi Y., Xue Y. \& Wang X. (2017). Release and Microbial Degradation of Dissolved Organic 644 Carbon and Nitrogen from Phragmites australis and Suaeda salsa in the Wetland of the $645 \quad$ Yellow River Estuary. Journal of Oceanography and Marine Research 05.

646 Qu X., Xie L., Lin Y., Bai Y., Zhu Y., Xie F., et al. (2013). Quantitative and qualitative 647 characteristics of dissolved organic matter from eight dominant aquatic macrophytes. 648 Environmental science and pollution research international 20, 7413-7423.

649 Reitsema R.E., Meire P. \& Schoelynck J. (2018). The Future of Freshwater Macrophytes in a 650 Changing World: Dissolved Organic Carbon Quantity and Quality and Its Interactions 651 With Macrophytes. Frontiers in Plant Science 9, 1-15.

652 Saidy A.R., Smernik R.J., Baldock J.A., Kaiser K. \& Sanderman J. (2013). Geoderma The 653 sorption of organic carbon onto differing clay minerals in the presence and absence of 654 hydrous iron oxide. Geoderma 209-210, 15-21.

655 Sepp M., Kõiv T., Nõges P. \& Nõges T. (2019). The role of catchment soils and land cover on 656 dissolved organic matter (DOM) properties in temperate lakes. Journal of Hydrology $657 \quad \mathbf{5 7 0}, 281-291$.

658 Simon Sz., Mádl-Szőnyi J., Müller I., \& Pogácsás Gy. (2011). Conceptual model for surface 
659

660

661

662

663

664

665

666

667

668

669

670

671

672

673

674

675

676

677

678

679

680

681

682

683

salinization in an overpressured and a superimposed gravity-flow field, Lake

Kelemenszék area, Hungary. Hydrogeology Journal 19, 701-717.

Sobek A.S., Söderbäck B., Karlsson S., Andersson E., Karlsson S., Andersson E., et al. (2006). A Carbon Budget of a Small Humic Lake : An Example of the Importance of Lakes for Organic Matter Cycling in Boreal Catchments A Carbon Budget of a Small Humic Lake : An Example of the Importance of Lakes for Organic Matter Cycling in Boreal Catchments. AMBIO: A Journal of the Human Environment 35, 469-475

Sobek S., Tranvik L.J., Prairie Y.T., Kortelainen P. \& Cole J.J. (2007). Patterns and regulation of dissolved organic carbon: An analysis of 7,500 widely distributed lakes. Limnology and Oceanography 52, 1208-1219.

Szabó A., Korponai K., Kerepesi C., Somogyi B., Vörös L., Bartha D., et al. (2017). Soda pans of the Pannonian steppe harbor unique bacterial communities adapted to multiple extreme conditions. Extremophiles 21, 1-11.

Székely, A. J., M. Berga, and S. Langenheder. 2013. Mechanisms determining the fate of dispersed bacterial communities in new environments. ISME J. 7: 61-71.

Thurman E.M. (1985). Organic Geochemistry of Natural Waters. Martinus Nijhoff/Dr. W. Junk Publishers, Dordrecht, the Netherlands.

Tranvik L. J. (1988). Availability of dissolved organic carbon for planktonic bacteria in oligotrophic lakes of differing humic content. Microbial Ecology 16, 311-322

Tranvik L.J., Cole J.J. \& Prairie Y.T. (2018). The study of carbon in inland waters-from isolated ecosystems to players in the global carbon cycle. Limnology and Oceanography Letters 3, 41-48.

Verpoorter, C., T. Kutser, D. A. Seekell, and L. J. Tranvik. 2014. A global inventory of lakes based on high-resolution satellite imagery. Geophys. Res. Lett. 41: 6396-6402.

V.-Balogh K., Presing M., Hiripi L. \& Vörös L. (1998). Stable carbon and nitrogen isotope 
684 ratios of dissolved humic substances in a shallow reservoir covered by macrophytes. $685 \quad$ Internat. Rev. Hydrobiol. 83, 203-206

686 V.-Balogh K., Présing M., Vörös L. \& Tóth N. (2006). A study of the decomposition of reed 687 (Phragmites australis) as a possible source of aquatic humic substances by measuring the 688 natural abundance of stable carbon isotopes. International Review of Hydrobiology $\mathbf{9 1 ,}$ $689 \quad 15-28$.

690 V.-Balogh, K., Németh, B. \& Vörös, L. (2009). Specific attenuation coefficients ofoptically 691 active substances and their contribution to the underwaterultraviolet and visible light 692 climate in shallow lakes and ponds. Hydrobiologia 632, 91-105.

693 Warren J.K. (2006). Depositional chemistry and hydrology, Evaporites: Sediments, Resources 694 and Hydrocarbons. pp. 59-138. Springer-Verlag, Berlin, Heidelberg.

695 Wetzel R. (2001). Limnology: Lake and River Ecosystems., Third. Academic Press, San 696 Diego.

697 Williamson C.E., Morris D.P., Pace M.L. \& Olson O.G. (1999). Dissolved organic carbon and 698 nutrients as regulators of lake ecosystems: Resurrection of a more integrated paradigm. 699 Limnology and Oceanography 44, 795-803.

700 Zhang Y., Liu X., Wang M. \& Qin B. (2013). Compositional differences of chromophoric 701 dissolved organic matter derived from phytoplankton and macrophytes. Organic $702 \quad$ Geochemistry 55, 26-37. 
704 Figure legends

705 Fig. 1 Global mean (a) and maximum (b) concentrations of dissolved organic carbon (DOC) in 706 inland waters. Data sources: (Wetzel, 2001) for surface water; (Chen et al., 2015) for lakes; 707 (Thurman, 1985) for lakes, swamps, marshes, bogs; Suhett et al (2004) for coastal lagoons; 708 (Boros et al., 2013, 2016, 2017) for soda pans.

709

710 Fig. 2 Location of studied soda pans within the Carpathian Basin based on Boros et al., 2017.

711

712 Fig. 3 Multisite comparison of the factors related to colored dissolved organic matter (CDOM) 713 in 14 soda pans of the Carpathian Basin. (a) Comparison of CDOM concentration in soda pans 714 and nearby groundwater; (b) Difference between CDOM concentration of soda pans and 715 corresponding groundwater well by dominant macrophyte type of the pans (Bolboschoenus 716 maritimus or Phragmites australis); (c) Correlation of groundwater and soda pan CDOM. Filled 717 circles indicate $B$. maritimus and crosses $P$. australis dominated pans, while the empty circle 718 indicates no macrophyte cover. Dashed line depicts non-significant $(r=0.643 ; p=0.168)$ and 719 solid line depicts significant $(r=0.804 ; p=0.029)$ correlation; (d) Variance of CDOM of the 72014 pans explained by the different parameters based on linear model (Table S4). Significance of parameters according to ANOVA indicated by **: $p<0.01 ;{ }^{*}: \mathrm{p}<0.05 ; \mathrm{p}<0.1$.

723 Fig. 4 Experimental organic matter release from Bolboschoenus maritimus and Phragmites 724 australis plant material. (a) Colored dissolved organic matter (CDOM) release. Non-linear 725 Michaelis-Menten kinetics-based curve fitting statistics for $B$. maritimus: $\mathrm{N}=28 ; \mathrm{df}=25 ; \mathrm{r}^{2}=$ $726 \quad 0.7881 ; \mathrm{V}_{\max }=4495.6372 \mathrm{p}<<0.0001 ; \mathrm{K}_{\mathrm{m}}=5.2482 \mathrm{p}=0.0023$, and for P. australis: $\mathrm{N}=28 ; \mathrm{df}=26$; $727 \mathrm{r}^{2}=0.8403 ; \mathrm{V}_{\max }=1308.8554 \mathrm{p}<<0.0001 ; \mathrm{K}_{\mathrm{m}}=5.2816 \mathrm{p}=0.0002$. (b) Dissolved organic matter 728 (DOC) release. Non-linear Michaelis-Menten kinetics-based curve fitting statistics for $B$. 
729 maritimus: $\mathrm{N}=28 ; \mathrm{df}=26 ; \mathrm{r}^{2}=0.9197 ; \mathrm{V}_{\max }=189.4330 \mathrm{p}<<0.0001 ; \mathrm{K}_{\mathrm{m}}=1.9014 \mathrm{p}<<0.0001$, and 730 for $P$. australis: $\mathrm{N}=28 ; \mathrm{df}=26 ; \mathrm{r}^{2}=0.8596 ; \mathrm{V}_{\max }=81.2560 \mathrm{p}<<0.0001 ; \mathrm{K}_{\mathrm{m}}=1.1827 \mathrm{p}<<0.0001$. 731 (c) Changes CDOM/DOC. Linear curve fitting statistics for $B$. maritimus: $\mathrm{N}=28 ; \mathrm{df}=26 ; \mathrm{r}^{2}=$ 732 0.5630; intercept $=15.7668 \mathrm{p}<<0.0001 ;$ slope $=0.2204 \mathrm{p}=0.0028$ and for P. australis: $\mathrm{N}=28$; $733 \mathrm{df}=26 ; \mathrm{r}^{2}=0.7529 ;$ intercept $=9.3597 \mathrm{p}<<0.0001 ;$ slope $=0.1896 \mathrm{p}<<0.0001$.

735 Fig. 5 Multiyear comparison of the temporal changes of environmental parameters in Sósér and 736 Zab-szék soda pans in 2014 and 2017. (a) Total suspended solids (TSS); (b) Mean water depth; 737 (c) $\mathrm{pH}$; (d) Electrical conductivity (EC); (e) Colored dissolved organic matter (CDOM); (f) 738 dissolved organic carbon (DOC).

739

740 Fig. 6 Temporal changes of dissolved organic matter (DOM) characterizing indices derived 741 from fluorescence excitation emission matrix spectroscopy (EEMS) in Sósér and Zab-szék soda 742 pans in 2017. (a) Fluorescence index (FI) indicating the source of DOM with high values (FI $\approx$ 743 1.8) suggesting DOM derived from extracellular release and leachate from bacteria and algae, 744 and low values $(\mathrm{FI} \approx 1.2)$ indicating plant and soil derived organic matter. (b) Freshness index 745 (FRESH) indicating contribution of recently produced DOM. (c) Humification index (HIX) 746 indicating humic substance content or extent of humification of DOM (Fellman et al., 2010). 
747 Table 1. Environmental parameters determined for the soda pans and corresponding groundwater wells in the multisite comparison

\begin{tabular}{|c|c|c|c|c|c|c|c|c|c|c|c|c|c|}
\hline & \multicolumn{9}{|c|}{ Soda pan } & \multicolumn{4}{|c|}{ Groundwater well } \\
\hline Name of pan & $\begin{array}{c}\text { Chemical } \\
\text { type }^{*}\end{array}$ & $\begin{array}{l}\text { Optical } \\
\text { type }^{\dagger}\end{array}$ & $\begin{array}{c}\text { Emergent } \\
\text { macrophyte } \\
\text { cover }(\%)\end{array}$ & \begin{tabular}{|c|} 
Macrophyte \\
type \\
(species \\
cover $>50 \%)$
\end{tabular} & $\begin{array}{c}\mathrm{TSS} \\
\left(\mathrm{mg} \mathrm{L}^{-1}\right)\end{array}$ & $\begin{array}{c}\text { Electrical } \\
\text { conductivity } \\
\left(\mu \mathrm{S} \mathrm{cm}^{-1}\right)\end{array}$ & $\mathrm{pH}$ & $\begin{array}{c}\text { CDOM } \\
(\text { Pt mg L-1) }\end{array}$ & $\begin{array}{l}\text { Water } \\
\text { depth } \\
(\mathrm{cm})\end{array}$ & $\begin{array}{c}\text { Electrical } \\
\text { conductivity } \\
\left(\mu \mathrm{S} \mathrm{cm}^{-1}\right)\end{array}$ & $\mathrm{pH}$ & $\begin{array}{c}\mathrm{CDOM} \\
\left(\mathrm{Pt} \mathrm{mg} \mathrm{L}{ }^{-1}\right)\end{array}$ & $\begin{array}{l}\text { Distance to } \\
\text { closest shore } \\
\text { of soda pan } \\
\text { (m) }\end{array}$ \\
\hline Bogárzó & Soda & Turbid & 43 & B. maritimus & 807 & 4970 & 9.28 & 1424 & 30 & 5460 & 8.55 & 107 & 34 \\
\hline Böddi-szék 1 & Soda-Saline & Turbid & 15 & P. australis & 745 & 6420 & 9.80 & 239 & 9 & 2810 & 8.83 & 74 & 24 \\
\hline Böddi-szék 2 & Soda-Saline & Turbid & 5 & P. australis & 1100 & 1710 & 9.69 & 253 & 2 & 5100 & 9.56 & 117 & 16 \\
\hline Böddi-szék 3 & Soda-Saline & Colored & 92 & P. australis & 8 & 1847 & 8.39 & 293 & 40 & 3400 & 9.29 & 303 & 239 \\
\hline Büdös-szék & Soda & Turbid & 62 & B. maritimus & 384 & 5230 & 9.27 & 174 & 12 & 2200 & 7.73 & 28 & 190 \\
\hline Csaba-szék & Soda & Colored & 52 & B. maritimus & 50 & 2620 & 8.57 & 1659 & 20 & 1863 & 8.34 & 841 & 25 \\
\hline Dongér & Soda-Saline & Turbid & 11 & P. australis & 67 & 1625 & 10.57 & 99 & 20 & 757 & 8.64 & 67 & 31 \\
\hline Fehér-szék & Soda & Turbid & 91 & P. australis & 585 & 3300 & 8.86 & 684 & 45 & 2310 & 8.74 & 437 & 155 \\
\hline Fülöp-szék & Soda & Colored & 75 & P. australis & 350 & 4090 & 9.12 & 143 & 8 & 4010 & 7.02 & 28 & 198 \\
\hline Kelemen-szék & Soda & Turbid & 30 & B. maritimus & 1850 & 3010 & 9.13 & 693 & 20 & 1146 & 8.15 & 205 & 201 \\
\hline Sósér & Soda & Colored & 95 & B. maritimus & 83 & 8680 & 9.89 & 2088 & 3 & 3540 & 9.28 & 69 & 47 \\
\hline Unnamed & Soda & Turbid & 0 & none & 692 & 4840 & 9.43 & 203 & 20 & 1609 & 8.73 & 146 & 85 \\
\hline Vesszős-szék & Soda & Turbid & 72 & B. maritimus & 80 & 2050 & 9.73 & 282 & 20 & 1678 & 8.17 & 41 & 467 \\
\hline Zab-szék & Soda & Turbid & 16 & P. australis & 1574 & 4270 & 9.28 & 364 & 3 & 1051 & 8.30 & 667 & 45 \\
\hline
\end{tabular}

$748 *$ Based on Boros \& Kolpakova (2018)

$749 \dagger$ Based on Boros et al., $(2013,2017)$ 
751 Table 2. Mean and standard deviation of the measured parameters of the turbid and colored

752 soda pan in the two years of seasonal monitoring

\begin{tabular}{|c|c|c|c|c|c|c|c|c|}
\hline \multirow{3}{*}{ Parameter } & \multicolumn{4}{|c|}{ Sósér } & \multicolumn{4}{|c|}{ Zab-szék } \\
\hline & \multicolumn{2}{|c|}{2014} & \multicolumn{2}{|c|}{2017} & \multicolumn{2}{|c|}{2014} & \multicolumn{2}{|c|}{2017} \\
\hline & Mean & SD & Mean & SD & Mean & SD & Mean & SD \\
\hline TSS & 180.8 & 293.0 & 68.7 & 71.1 & 2325.9 & 2201.9 & 2100.9 & 1618.3 \\
\hline Depth & 18.6 & 15.3 & 26.8 & 14.3 & 13.1 & 12.1 & 11.3 & 9.6 \\
\hline $\mathrm{pH}$ & 9.26 & 0.54 & 9.23 & 0.40 & 9.60 & 0.28 & 9.61 & 0.21 \\
\hline EC & 5.72 & 3.45 & 6.49 & 3.79 & 5.64 & 3.66 & 7.05 & 6.68 \\
\hline CDOM & 5888.7 & 2908.6 & 1628.2 & 508.7 & 470.4 & 200.8 & 279.1 & 127.3 \\
\hline DOC & 437.3 & 268.5 & 214.6 & 108.4 & 69.1 & 48.0 & 49.4 & 10.8 \\
\hline FI & - & & 1.228 & 0.028 & - & - & 1.234 & 0.049 \\
\hline FRESH & - & - & 0.608 & 0.030 & - & - & 0.736 & 0.091 \\
\hline HIX & - & - & 17.47 & 1.689 & - & - & 7.143 & 1.436 \\
\hline
\end{tabular}

753 
755 Table 3. Results of cross-correlation at lag $=0$ of colored dissolved organic matter (CDOM)

756 and dissolved organic carbon (DOC) and environmental parameters of the turbid and colored

757 soda pans. Significant correlations $(\mathrm{p}<0.05)$ are in bold.

\begin{tabular}{l|c|c|c|c|c|c}
\multirow{2}{*}{} & \multicolumn{3}{c|}{ CDOM } & \multicolumn{3}{c}{ DOC } \\
\cline { 2 - 7 } & \multicolumn{2}{|c|}{ Sósér } & Zab-szék* & \multicolumn{2}{c}{ Sósér } & Zab-szék* \\
\cline { 2 - 7 } & 2014 & 2017 & 2014 & 2014 & 2017 & 2014 \\
\hline TSS & 0.316 & 0.598 & 0.355 & $\mathbf{0 . 7 3 7}$ & $\mathbf{0 . 7 4 5}$ & 0.122 \\
Depth & $\mathbf{- 0 . 7 5 0}$ & $\mathbf{- 0 . 8 2 9}$ & $\mathbf{0 . 8 0 9}$ & $\mathbf{- 0 . 7 5 8}$ & $\mathbf{- 0 . 7 7 8}$ & $\mathbf{0 . 6 2 2}$ \\
pH & $\mathbf{0 . 7 7 8}$ & 0.563 & $\mathbf{- 0 . 7 9 2}$ & $\mathbf{0 . 9 3 0}$ & $\mathbf{0 . 8 3 9}$ & 0.414 \\
Conductivity & $\mathbf{0 . 8 0 2}$ & $\mathbf{0 . 6 6 0}$ & -0.447 & $\mathbf{0 . 9 9 4}$ & $\mathbf{0 . 8 7 0}$ & $\mathbf{0 . 9 5 1}$ \\
FI & & -0.297 & & & -0.568 & \\
FRESH & & 0.181 & & & $\mathbf{0 . 8 0 9}$ & \\
HIX & & -0.225 & & & -0.125 & \\
\hline
\end{tabular}

$758 *$ Measurements from 2017 for Zab-szék were omitted from these analyses because of missing 759 data due to drought of the pan.

760

761 
762 Figure 1

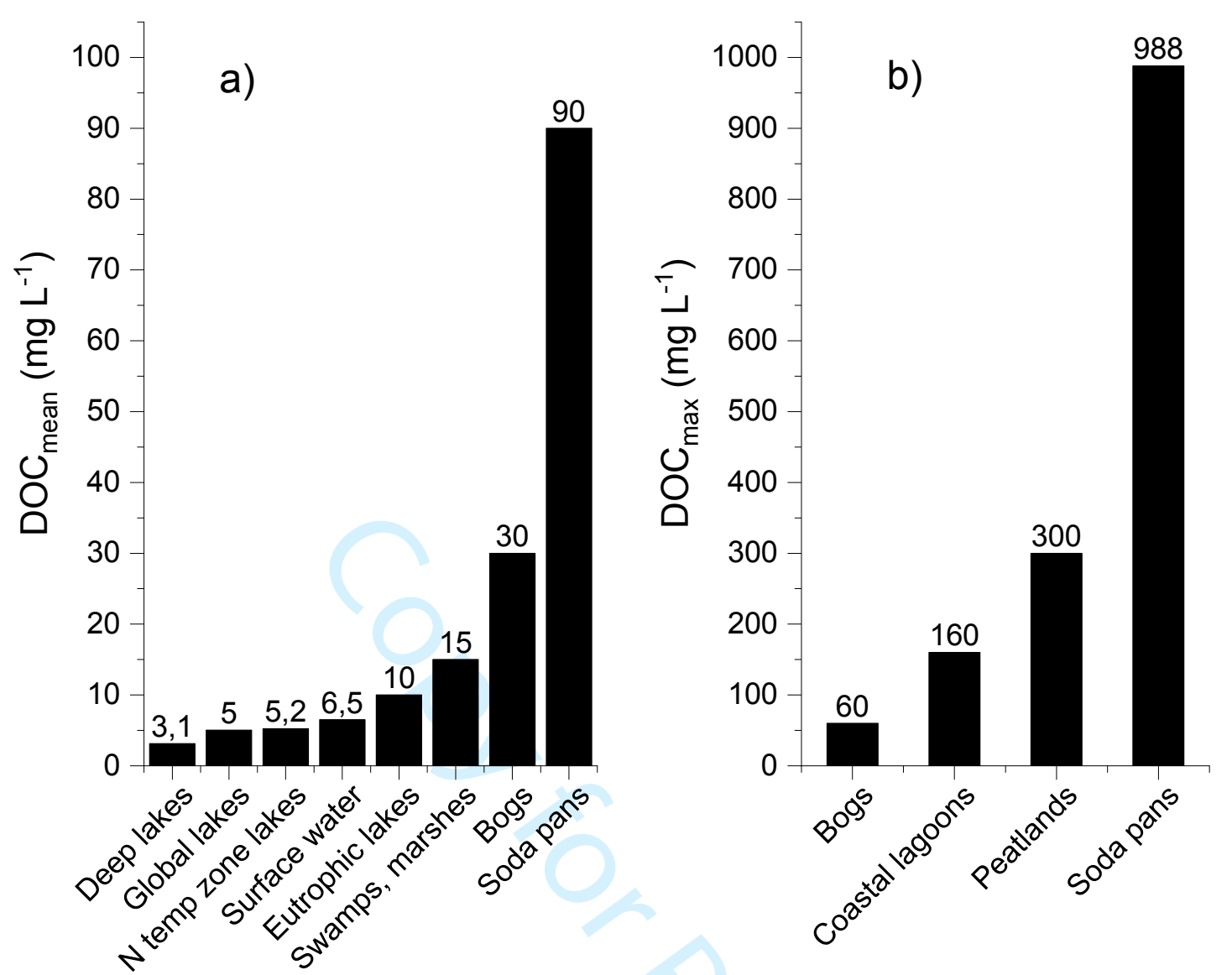

763

764 
765 Figure 2

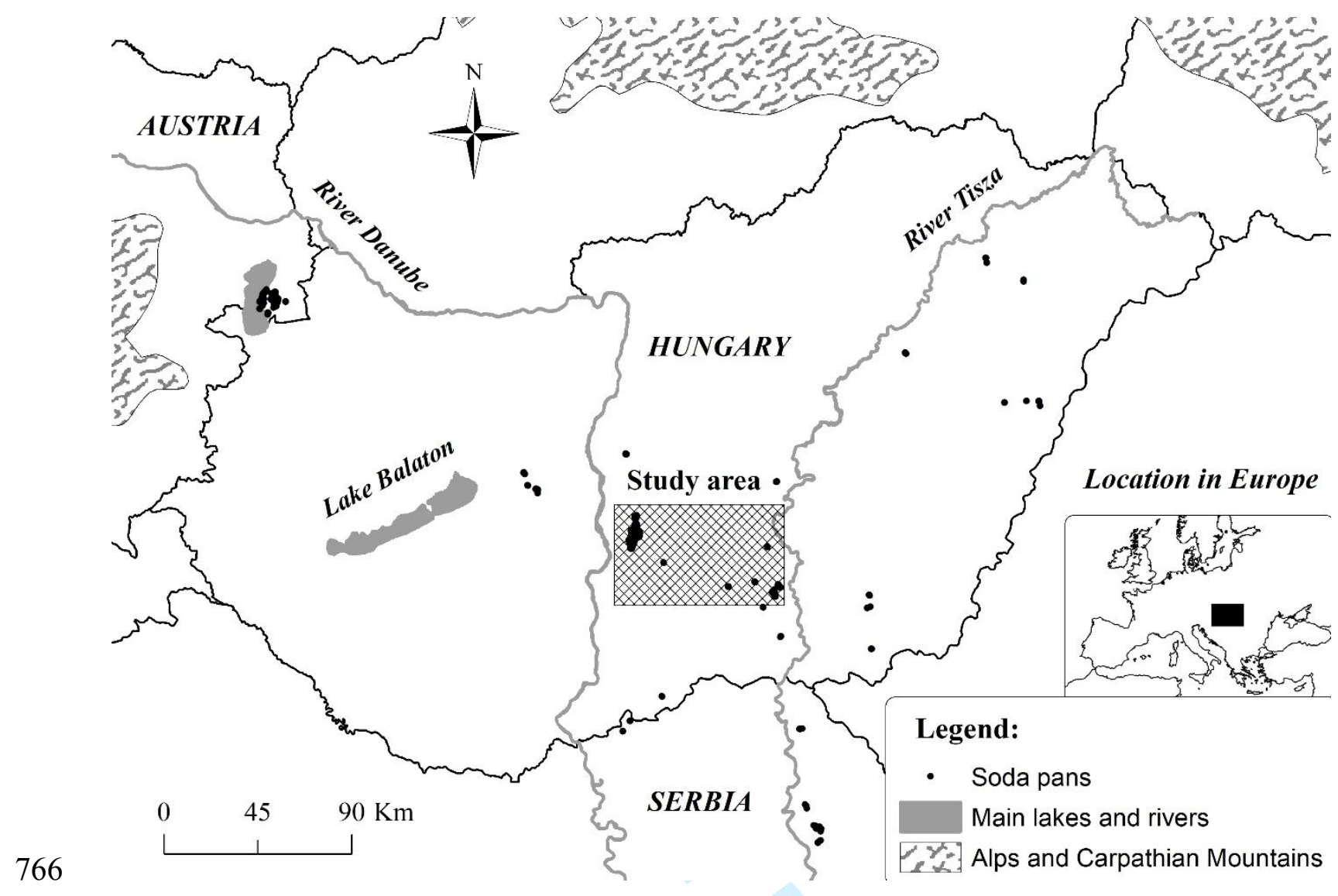


769 Figure 3

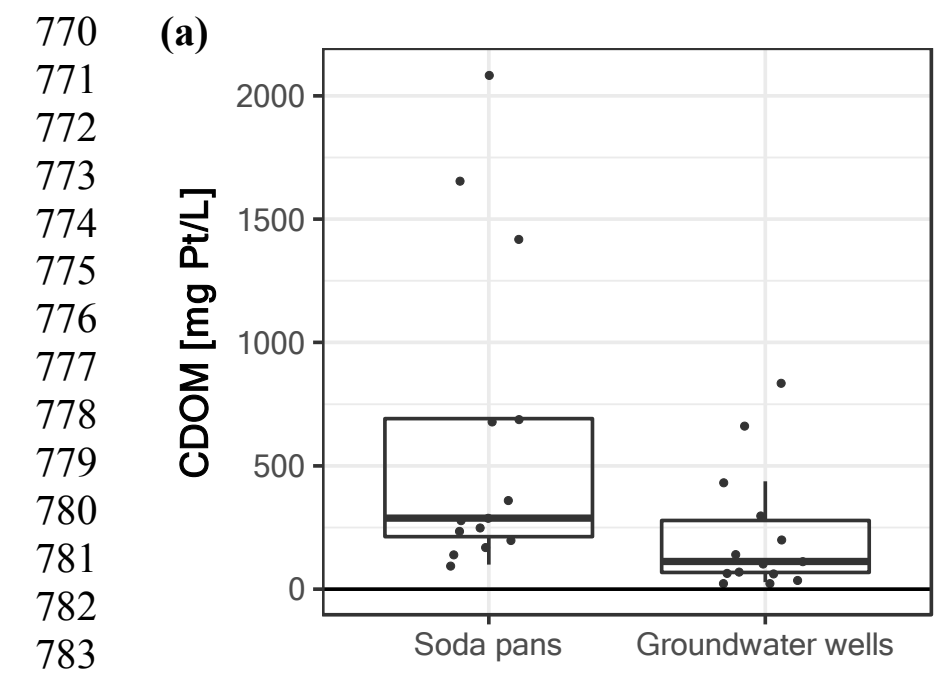

(b)

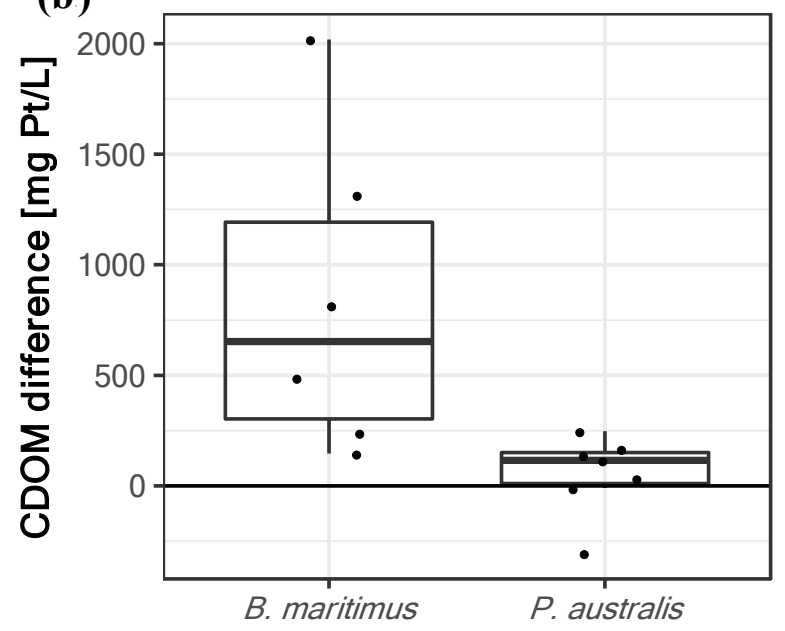

784

785

786

787

(c)

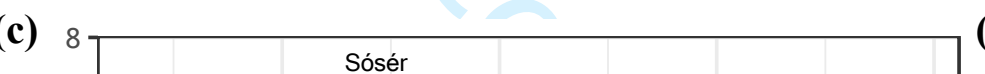

(d)

788

789

790

791

792
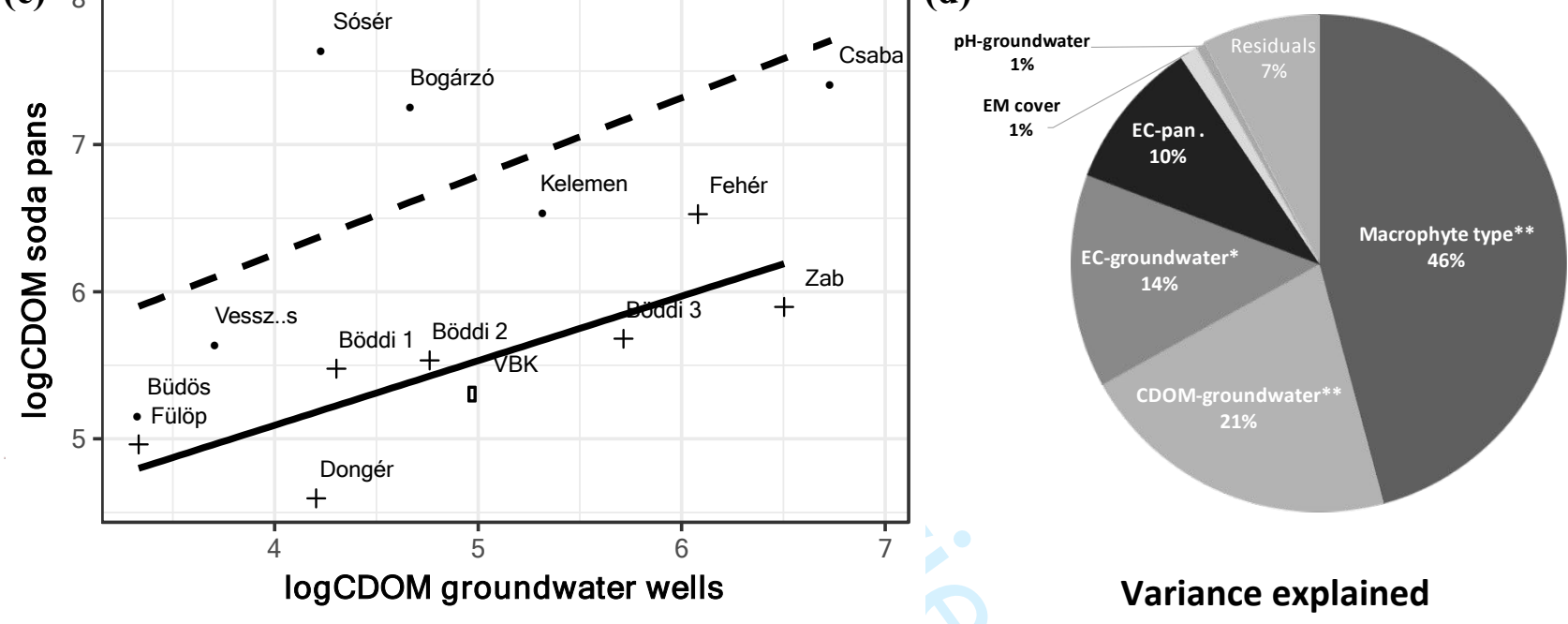

Variance explained 
$793 \quad$ Figure 4

$794 \quad$ (a)

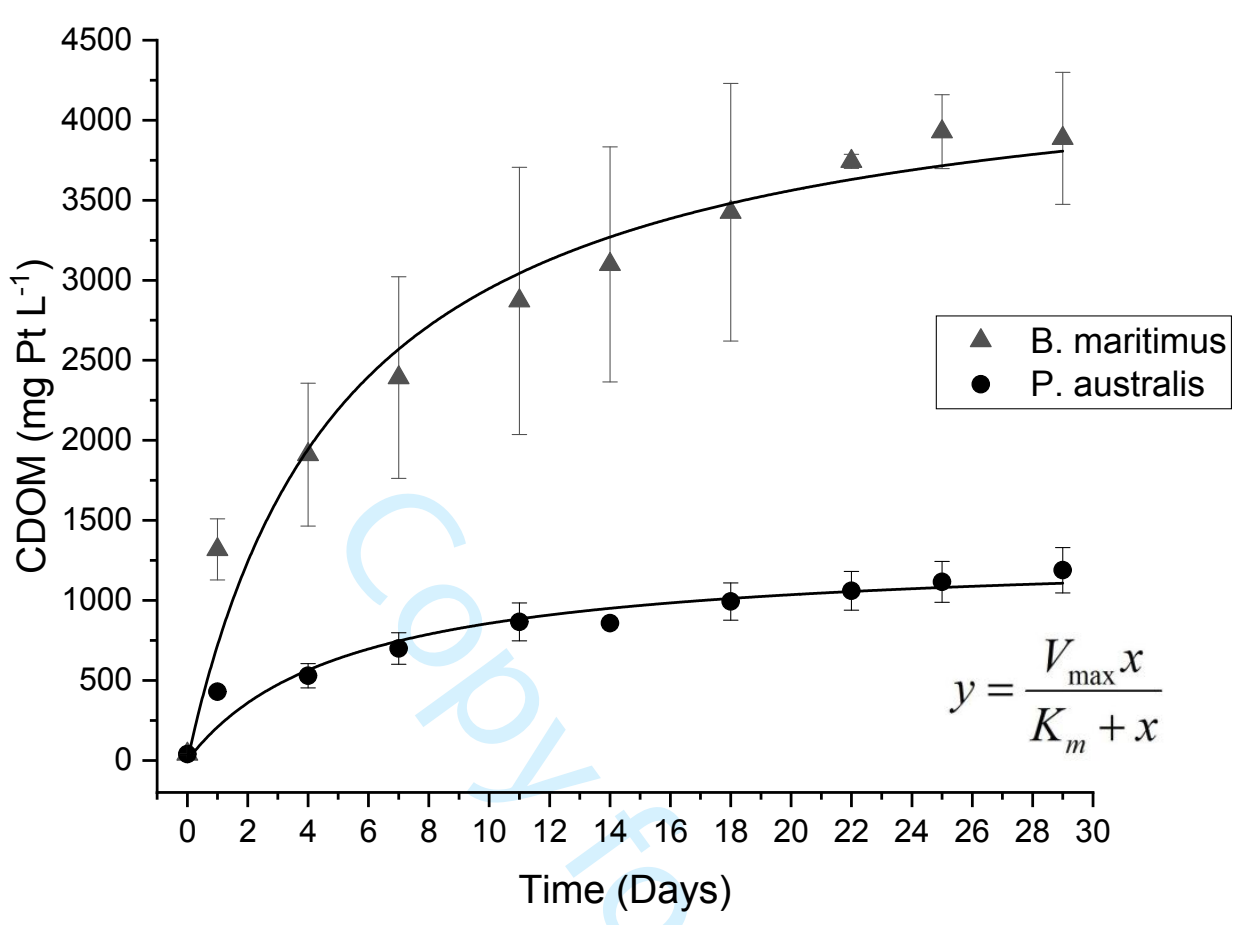

795

796

797

(b)

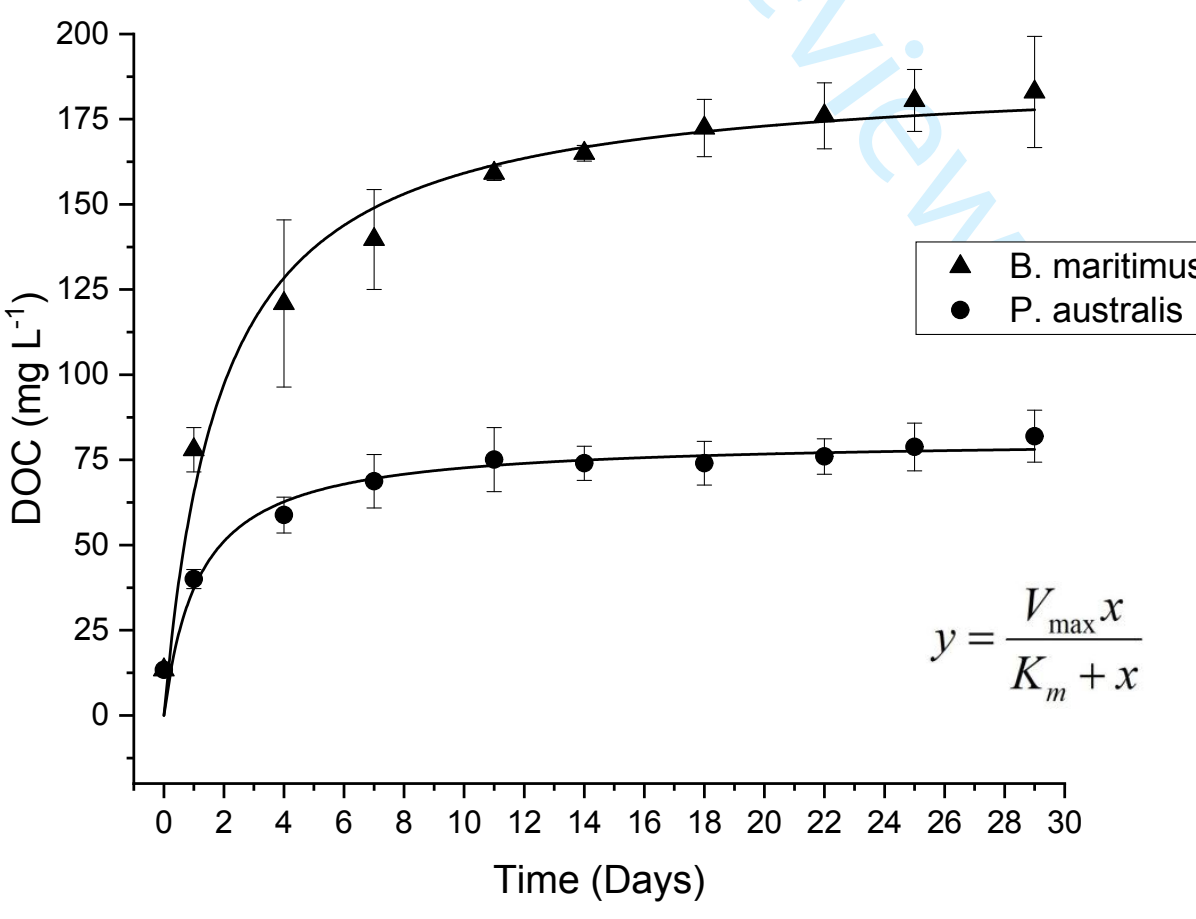


800

801

(c)

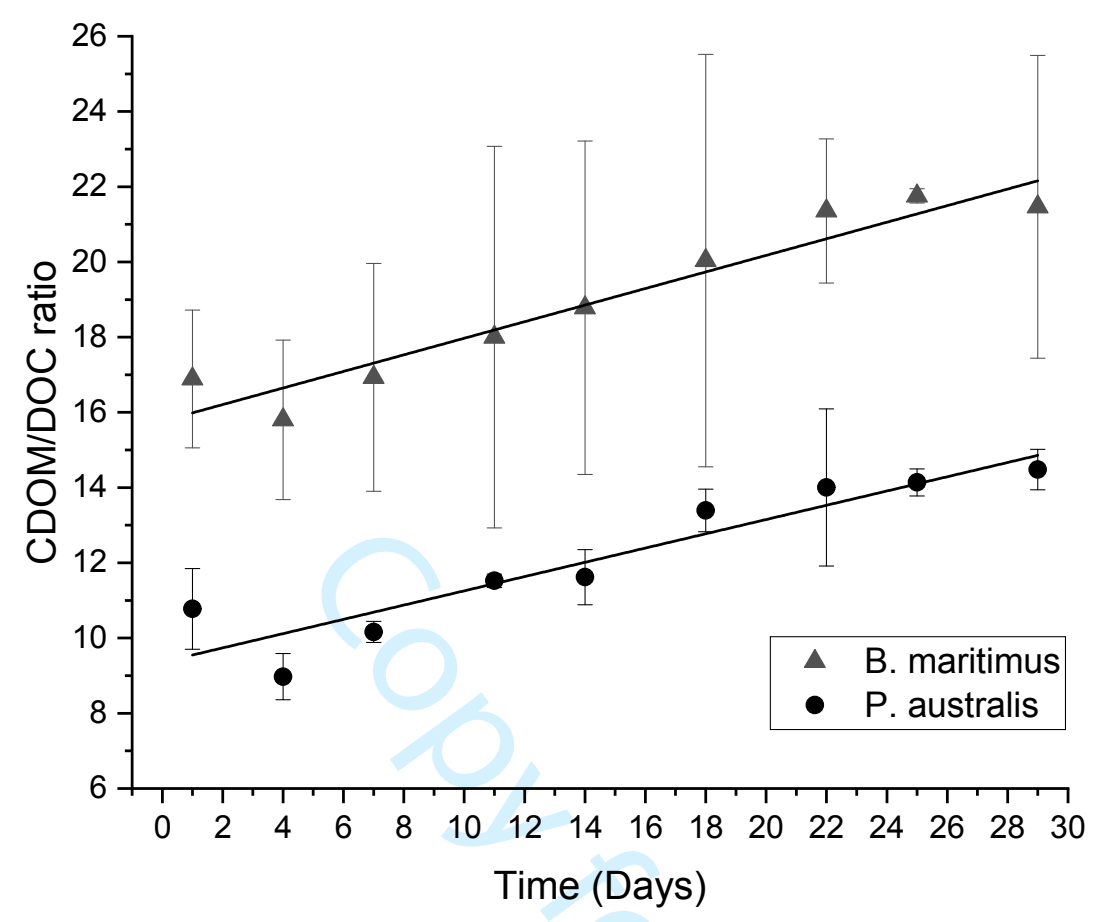

802

803 
$804 \quad$ Figure 5
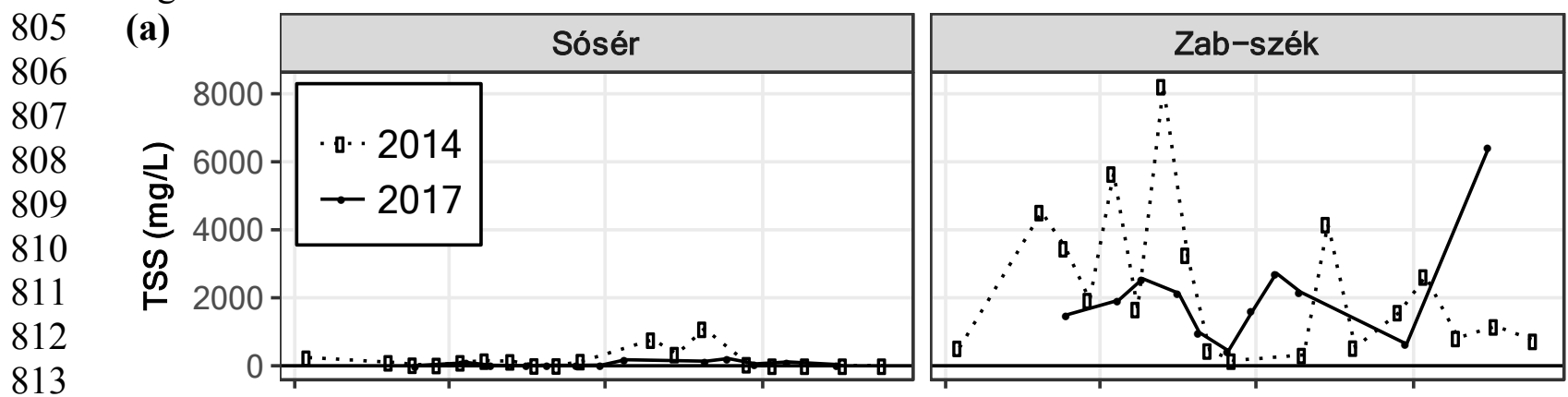

814

815

816

817

818

819

820

821

(b)
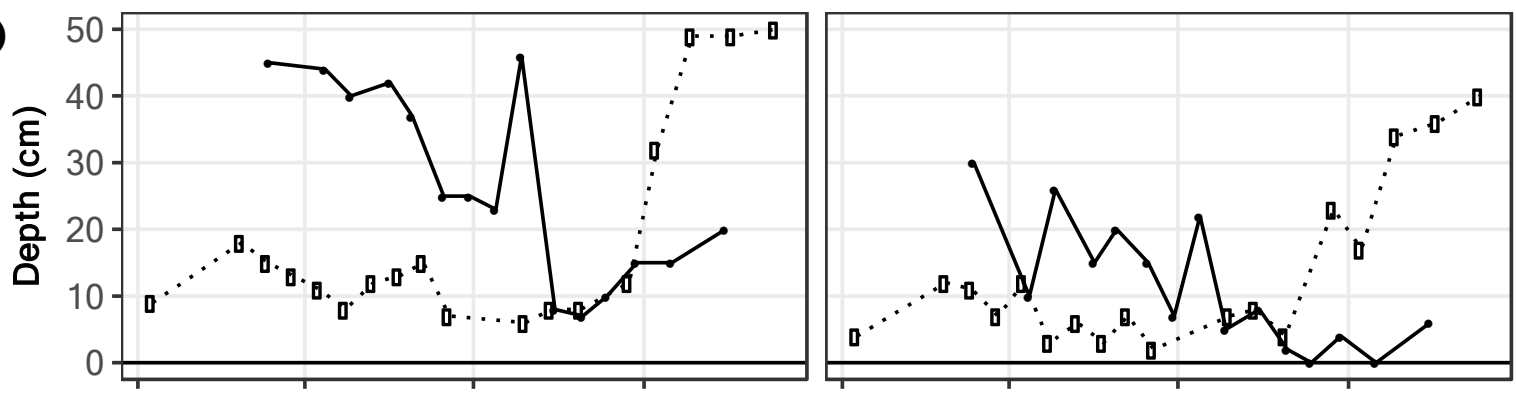

822

823

824

825

826

827

828

829

830

(c)
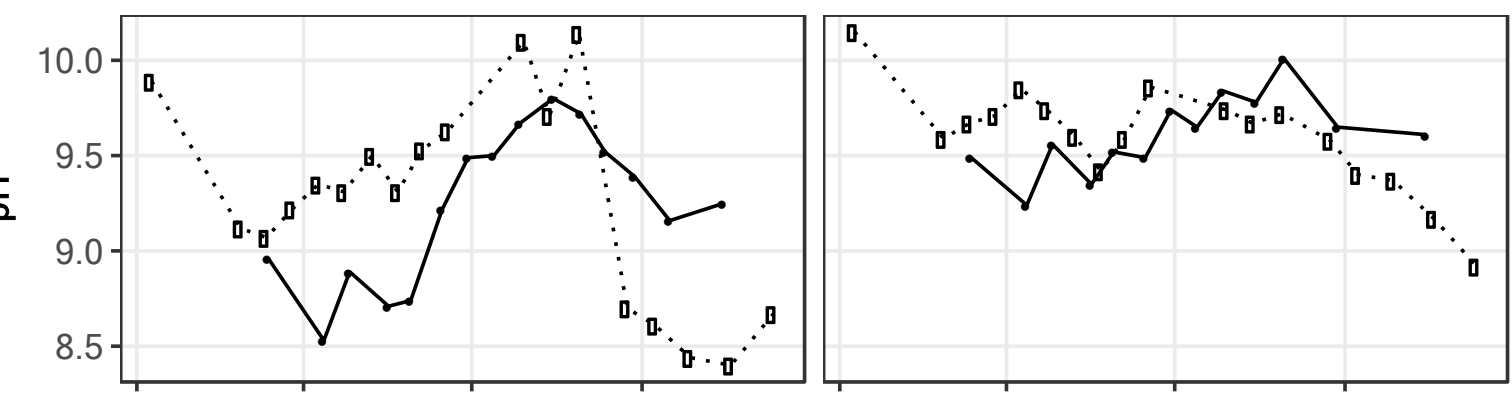

(d)
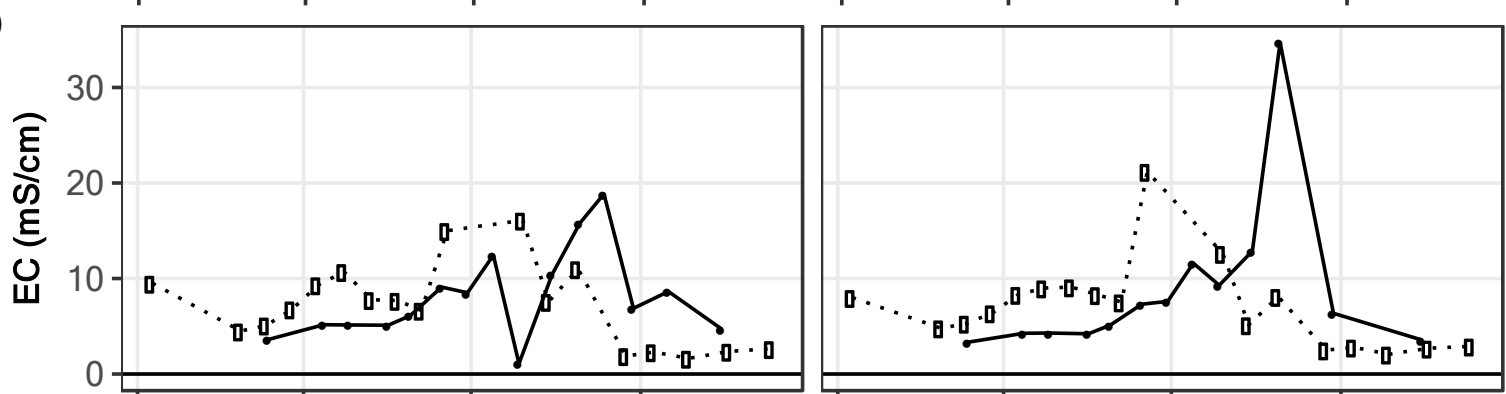

838

839

(e)
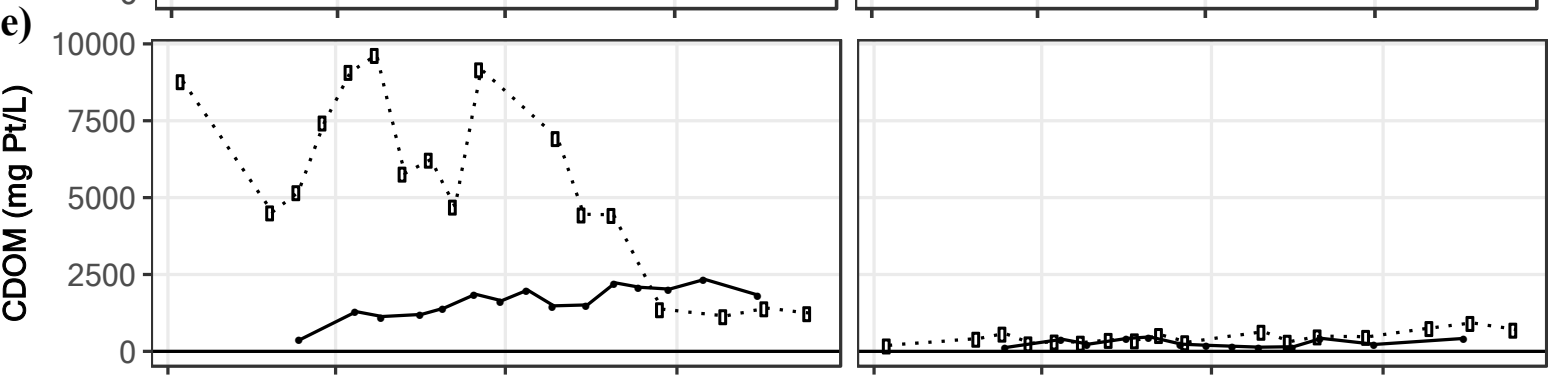

845

846

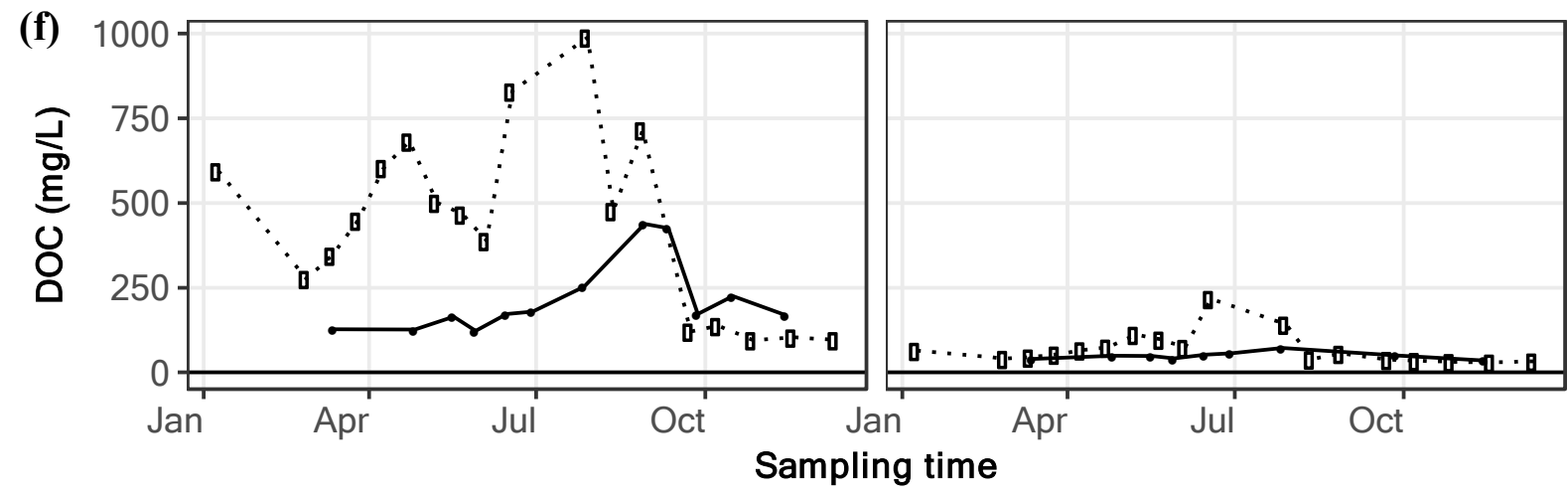


847 Figure 6

848

849

850

851

852

853

854

855

856

857

858

859

860

861

862

863

864

865

866

867

868

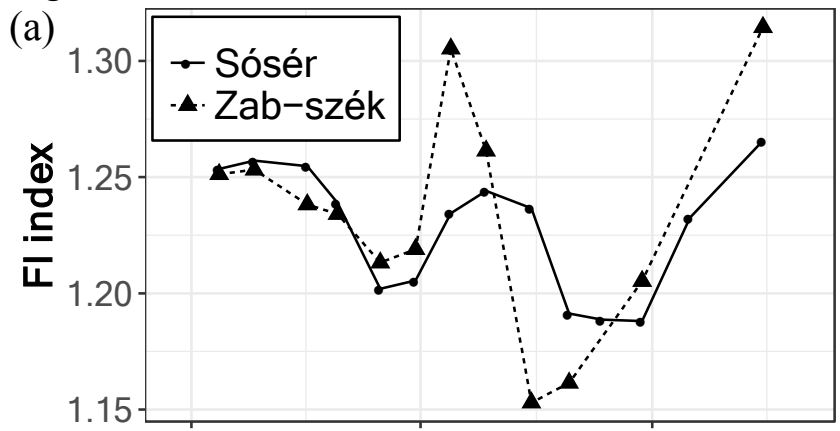

(b)

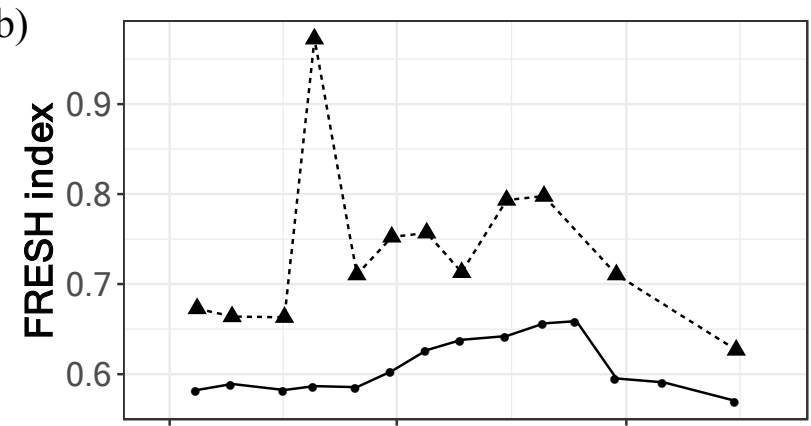

(c)

869

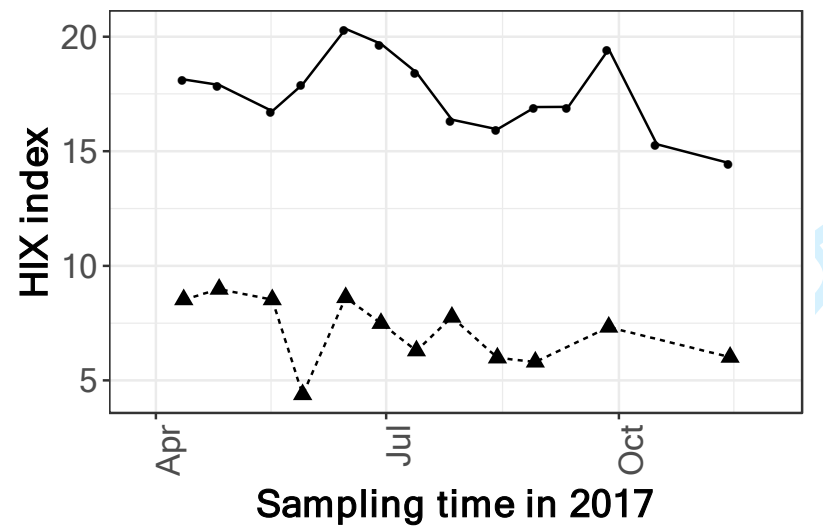


Table S1. Coordinates of soda pans and groundwater wells studied I the cross-sectional analyses.

\begin{tabular}{|c|c|c|c|c|}
\hline & \multicolumn{2}{|c|}{ Soda pans } & \multicolumn{2}{|c|}{ Groundwater wells } \\
\hline Name of pan & $\begin{array}{l}\text { Latitude } \\
\qquad(\mathrm{N})\end{array}$ & $\begin{array}{l}\text { Longitude } \\
\text { (E) }\end{array}$ & $\begin{array}{c}\text { Latitude } \\
\text { (N) }\end{array}$ & $\begin{array}{c}\text { Longitude } \\
\text { (E) }\end{array}$ \\
\hline Bogárzó & 46.8054 & 19.1412 & 46.8045 & 19.1403 \\
\hline Böddi-szék 1 & 46.7666 & 19.1500 & 46.7688 & 19.1500 \\
\hline Böddi-szék 2 & 46.7603 & 19.1476 & 46.7604 & 19.1463 \\
\hline Böddi-szék 3 & 46.7692 & 19.1229 & 46.7684 & 19.1246 \\
\hline Büdös-szék & 46.5467 & 20.0298 & 46.5489 & 20.0259 \\
\hline Csaba-szék & 46.8182 & 19.1888 & 46.8179 & 19.1875 \\
\hline Dongér & 46.5725 & 20.0593 & 46.5725 & 20.0583 \\
\hline Fehér-szék & 46.8083 & 19.1867 & 46.8106 & 19.1845 \\
\hline Fülöp-szék & 46.5787 & 19.9877 & 46.5775 & 19.9889 \\
\hline Kelemen-szék & 46.7973 & 19.1743 & 46.8012 & 19.1717 \\
\hline Sósér & 46.7877 & 19.1350 & 46.7866 & 19.1355 \\
\hline Unknown & 46.7636 & 19.1807 & 46.7642 & 19.1807 \\
\hline Vesszős-szék & 46.5249 & 20.0373 & 46.5249 & 20.0310 \\
\hline Zab-szék & 46.8342 & 19.1748 & 46.8352 & 19.1747 \\
\hline
\end{tabular}


Table S2. Summary of backward selection of parameter for AIC minimalization

Initial model:

$\log \left(\mathrm{CDOM}_{\text {soda pans }}\right) \sim \log \left(\mathrm{CDOM}_{\text {groundwater wells }}\right)+$ Conductivity $_{\text {soda pans }}+$ Conductivity $_{\text {groundwater }}$ wells $+\mathrm{pH}_{\text {soda pans }}+\mathrm{pH}_{\text {groundwater wells }}+$ Emerged macrophyte type + Emerged macrophyte cover + Depth + TSS + Chemical type + Optical type

Model after backward selection:

$\log \left(\mathrm{CDOM}_{\text {soda pans }}\right) \sim \log \left(\mathrm{CDOM}_{\text {groundwater wells }}\right)+$ Conductivity $_{\text {soda pans }}+$ Conductivity $_{\text {groundwater }}$ wells $+\mathrm{pH}_{\text {soda pans }}+\mathrm{pH}_{\text {groundwater wells }}+$ Emerged macrophyte type + Emerged macrophyte cover + TSS + Chemical type

\begin{tabular}{ccccccc} 
Step & $\begin{array}{c}\text { Removed } \\
\text { parameter }\end{array}$ & Df & Deviance & $\begin{array}{c}\text { Residual } \\
\text { S Df }\end{array}$ & $\begin{array}{c}\text { Residuals } \\
\text { Deviance }\end{array}$ & AIC \\
\hline 1 & & & 1 & 0.2145496 & $\begin{array}{c}32.49581 \\
\text { Depth }\end{array}$ \\
& & & 0.00065744 & 2 & 0.2152070 & $\begin{array}{c}34.45297 \\
3\end{array}$ \\
& Optical type & 1 & 0.00077518 & 3 & 0.2159822 & 36.40263
\end{tabular}


Table S3. Summary of GVIF (Generalized Variance Inflation Factors) analyses before and after removal of inflated parameters $\left(\operatorname{GVIF}^{\wedge}(1 /(2 * D f))^{\wedge} 2>5\right)$. Analyses were performed using vif function of car package in $\mathrm{R}$.

Final model after backward selection:

$\log \left(\mathrm{CDOM}_{\text {soda pans }}\right) \sim \log \left(\mathrm{CDOM}_{\text {groundwater wells }}\right)+$ Conductivity $_{\text {soda pans }}+$ Conductivity $_{\text {groundwater }}$ wells $+\mathrm{pH}_{\text {soda pans }}+\mathrm{pH}_{\text {groundwater wells }}+$ Emerged macrophyte type + Emerged macrophyte cover + TSS + Chemical type

\begin{tabular}{|c|c|c|c|}
\hline & GVIF & Df & $\operatorname{GVIF}^{\wedge}(1 /(2 * D f))$ \\
\hline $\log \left(\mathrm{CDOM}_{\text {groundwater wells }}\right)$ & 21.948539 & 1 & 4.684927 \\
\hline Conductivity $_{\text {groundwater wells }}$ & 4.796074 & 1 & 2.189994 \\
\hline Conductivity $_{\text {soda pans }}$ & 1.581812 & 1 & 1.257701 \\
\hline $\mathrm{pH}_{\text {groundwater wells }}$ & 20.822963 & 1 & 4.563218 \\
\hline $\mathrm{pH}_{\text {soda pans }}$ & 18.047921 & 1 & 4.248285 \\
\hline Emerged macrophyte type & 20.992869 & 2 & 2.140513 \\
\hline Emerged macrophyte cover & 21.216754 & 1 & 4.606165 \\
\hline TSS & 5.424868 & 1 & 2.329135 \\
\hline Chemical type & 24.508659 & 1 & 4.950622 \\
\hline
\end{tabular}

Model after removal of highest GVIF parameter (Chemical type):

$\log \left(\mathrm{CDOM}_{\text {soda pans }}\right) \sim \log \left(\mathrm{CDOM}_{\text {groundwater wells }}\right)+$ Conductivity $_{\text {soda pans }}+$ Conductivity $_{\text {groundwater }}$ wells $+\mathrm{pH}_{\text {soda pans }}+\mathrm{pH}_{\text {groundwater wells }}+$ Emerged macrophyte type + Emerged macrophyte cover + TSS

$\begin{array}{llcr} & \text { GVIF } & \text { Df } & \text { GVIF^(1/(2*Df)) }^{\wedge} \\ \log \left(\mathrm{CDOM}_{\text {groundwater wells }}\right) & 4.707523 & 1 & 2.169683 \\ \text { Conductivity } & 2.288839 & 1 & 1.512891 \\ \text { Conductivitwater wells }_{\text {soda pans }} & 1.551452 & 1 & 1.245573 \\ \mathrm{pH}_{\text {groundwater wells }} & 2.555346 & 1 & 1.598545 \\ \mathrm{pH}_{\text {soda pans }} & 5.345451 & 1 & 2.312023 \\ \text { Emerged macrophyte type } & 2.216132 & 2 & 1.22011 \\ \text { Emerged macrophyte cover } & 4.035098 & 1 & 2.008755 \\ \text { TSS } & 2.057321 & 1 & 1.434337\end{array}$

Final model after removal of highest GVIF parameter ( $\left.\mathrm{pH}_{\text {soda pans }}\right)$ :

$\log \left(\mathrm{CDOM}_{\text {soda pans }}\right) \sim \log \left(\mathrm{CDOM}_{\text {groundwater wells }}\right)+$ Conductivity $_{\text {soda pans }}+$ Conductivity $_{\text {groundwater }}$ wells $+\mathrm{pH}_{\text {soda pans }}+\mathrm{pH}_{\text {groundwater wells }}+$ Emerged macrophyte type + Emerged macrophyte cover + TSS

$\begin{array}{lccr} & \text { GVIF } & \text { Df } & \text { GVIF^(1/(2*Df) }) \\ \log \left(\mathrm{CDOM}_{\text {groundwater wells }}\right) & 1.740759 & 1 & 1.319378 \\ \text { Conductivity }_{\text {groundwater wells }} & 1.41167 & 1 & 1.188137 \\ \text { Conductivity }_{\text {soda pans }} & 1.337339 & 1 & 1.156434 \\ \mathrm{pH}_{\text {groundwater wells }} & 1.533761 & 1 & 1.238451 \\ \text { Emerged macrophyte type } & 1.615174 & 2 & 1.12734\end{array}$




$\begin{array}{llll}\text { Emerged macrophyte cover } & 2.270607 & 1 & 1.506853 \\ \text { TSS } & 1.955604 & 1 & 1.398429\end{array}$

Table S4. ANOVA table of the final linear model from table S3 ordered by variance explained. Significant correlations $(\mathrm{p}<0.05)$ are in bold. Significance codes: $p<0.001$ : '***'; $p<0.01$ : '**'; $p<0.05$ : $^{*}$ '; $p<0.1$ ',$; p>0.1$ ',

\begin{tabular}{|c|c|c|c|c|c|c|c|}
\hline & Df & Sum Sq & Mean Sq & F value & $\begin{array}{c}\operatorname{Pr} \\
(>\mathbf{F})\end{array}$ & $\begin{array}{c}\text { Variance } \\
\text { explained } \\
(\%)\end{array}$ & $\begin{array}{l}\text { Significance } \\
\text { code }\end{array}$ \\
\hline $\begin{array}{l}\text { Emerged macrophyte } \\
\text { type }\end{array}$ & 2 & 5.409892 & 2.704946 & 15.099960 & 0.007605 & 45.783090 & $* *$ \\
\hline $\begin{array}{l}\log \left(\mathrm{CDOM}_{\text {groundwater }}\right. \\
\text { wells })\end{array}$ & 1 & 2.499060 & 2.499060 & 13.950630 & 0.013500 & 21.149160 & $* *$ \\
\hline $\begin{array}{l}\text { Conductivity }{ }_{\text {groundwater }} \\
\text { wells }\end{array}$ & 1 & 1.646254 & 1.646254 & 9.189968 & 0.029032 & 13.932000 & $*$ \\
\hline Conductivity $_{\text {soda pans }}$ & 1 & 1.152705 & 1.152705 & 6.434803 & 0.052103 & 9.755164 & . \\
\hline $\begin{array}{l}\text { Emerged macrophyte } \\
\text { cover }\end{array}$ & 1 & 0.140855 & 0.140855 & 0.786304 & 0.415828 & 1.192038 & \\
\hline $\mathrm{pH}_{\text {groundwater wells }}$ & 1 & 0.071898 & 0.071898 & 0.401362 & 0.554230 & 0.608466 & \\
\hline TSS & 1 & 0.000009 & 0.000009 & 0.000051 & 0.994592 & 0.000077 & \\
\hline Residuals & 5 & 0.895680 & 0.179136 & NA & NA & 7.580003 & \\
\hline
\end{tabular}


Table S5. Results of cross-correlation analyses between CDOM and DOC concentrations and TSS, mean depth, pH, EC, and EEMS indexes (FI, FRESH and HIX) according to $x_{t+k} \sim y_{t}$, where $x_{t+k}$ is CDOM or DOM at timepoint $t+k$, and $y_{t}$ is the tested parameter at timepoint $t, k=1$ corresponds to 1 month lag. Significant correlations $(\mathrm{p}<0.05)$ are in bold. Only correlations between $k=-5$ and $k=5$ are presented as no greater lag crosscorrelations were significant.

\begin{tabular}{|c|c|c|c|c|c|c|c|c|c|c|c|c|c|}
\hline \multicolumn{2}{|l|}{ TSS } & \multirow[b]{2}{*}{ Yea } & \\
\hline Variable & Pan & & -5 & -4 & -3 & -2 & -1 & 0 & 1 & 2 & 3 & 4 & 5 \\
\hline CDOM & Sósér & 2014 & -0.159 & 0.227 & 0.331 & 0.181 & 0.37 & 0.316 & -0.188 & -0.412 & -0.378 & -0.4 & -0.126 \\
\hline CDOM & Sósér & 2017 & -0.376 & -0.566 & 0.049 & 0.265 & 0.314 & 0.598 & 0.407 & 0.323 & 0.108 & -0.218 & -0.296 \\
\hline CDOM & Zab-szék & 2014 & 0.182 & -0.183 & -0.049 & -0.097 & -0.479 & -0.355 & -0.311 & -0.016 & -0.156 & -0.333 & 0.045 \\
\hline DOC & Sósér & 2014 & -0.346 & -0.087 & 0.082 & 0.113 & 0.63 & 0.737 & -0.033 & -0.426 & -0.405 & -0.473 & -0.197 \\
\hline DOC & Sósér & 2017 & -0.219 & -0.416 & -0.356 & 0.143 & 0.482 & 0.745 & 0.666 & -0.058 & -0.363 & -0.343 & -0.282 \\
\hline DOC & Zab-szék & 2014 & -0.187 & -0.031 & -0.091 & -0.147 & -0.151 & -0.122 & 0.371 & 0.702 & 0.374 & 0.195 & 0.008 \\
\hline \multicolumn{14}{|l|}{ Depth } \\
\hline CDOM & Sósér & 2014 & 0.115 & -0.035 & -0.404 & -0.645 & -0.735 & -0.75 & -0.315 & -0.033 & 0.132 & 0.234 & 0.225 \\
\hline CDOM & Sósér & 2017 & 0.499 & -0.001 & -0.006 & -0.438 & -0.603 & -0.829 & -0.466 & -0.248 & 0.137 & 0.194 & 0.321 \\
\hline CDOM & Zab-szék & 2014 & 0.106 & 0.162 & 0.156 & 0.44 & 0.663 & 0.809 & 0.495 & 0.2 & -0.025 & -0.198 & -0.245 \\
\hline DOC & Sósér & 2014 & 0.447 & 0.446 & 0.037 & -0.453 & -0.718 & -0.758 & -0.377 & -0.093 & 0.043 & 0.134 & 0.165 \\
\hline DOC & Sósér & 2017 & 0.37 & 0.209 & -0.039 & -0.39 & -0.669 & -0.778 & -0.246 & -0.066 & 0.305 & 0.411 & 0.482 \\
\hline DOC & Zab-szék & 2014 & 0.738 & 0.449 & 0.068 & -0.287 & -0.598 & -0.622 & -0.429 & -0.227 & -0.06 & 0.048 & 0.041 \\
\hline \multicolumn{14}{|l|}{ pH } \\
\hline CDOM & Sósér & 2014 & -0.212 & 0.072 & 0.277 & 0.425 & 0.626 & 0.778 & 0.267 & -0.024 & -0.113 & -0.376 & -0.22 \\
\hline CDOM & Sósér & 2017 & -0.437 & -0.44 & -0.264 & 0.324 & 0.57 & 0.563 & 0.418 & 0.349 & 0.126 & -0.124 & -0.372 \\
\hline CDOM & Zab-szék & 2014 & -0.133 & 0 & -0.116 & -0.34 & -0.564 & -0.792 & -0.358 & -0.165 & -0.001 & 0.065 & 0.014 \\
\hline DOC & Sósér & 2014 & -0.403 & -0.35 & -0.145 & 0.124 & 0.646 & 0.93 & 0.406 & 0.035 & -0.113 & -0.371 & -0.237 \\
\hline DOC & Sósér & 2017 & -0.226 & -0.324 & -0.304 & -0.066 & 0.444 & 0.839 & 0.726 & 0.254 & -0.431 & -0.598 & -0.365 \\
\hline DOC & Zab-szék & 2014 & -0.664 & -0.275 & 0.111 & 0.339 & 0.441 & 0.414 & 0.096 & 0.009 & 0.103 & 0.099 & 0.201 \\
\hline
\end{tabular}




\begin{tabular}{|c|c|c|c|c|c|c|c|c|c|c|c|c|c|}
\hline \multicolumn{2}{|l|}{ EC } & \multirow[b]{2}{*}{ Yea } & \multicolumn{11}{|c|}{$\mathbf{k}$} \\
\hline Variable & Pan & & -5 & -4 & -3 & -2 & -1 & 0 & 1 & 2 & 3 & 4 & 5 \\
\hline CDOM & Sósér & 2014 & -0.209 & 0.017 & 0.394 & 0.36 & 0.535 & 0.802 & 0.304 & -0.051 & -0.171 & -0.432 & -0.41 \\
\hline CDOM & Sósér & 2017 & -0.593 & -0.179 & -0.161 & 0.173 & 0.236 & 0.66 & 0.529 & 0.349 & -0.032 & -0.096 & -0.22 \\
\hline CDOM & Zab-szék & 2014 & -0.179 & -0.108 & -0.246 & -0.369 & -0.384 & -0.447 & -0.377 & -0.338 & 0.061 & 0.444 & 0.502 \\
\hline DOC & Sósér & 2014 & -0.39 & -0.337 & -0.053 & 0.015 & 0.469 & 0.994 & 0.542 & 0.059 & -0.066 & -0.389 & -0.464 \\
\hline DOC & Sósér & 2017 & -0.322 & -0.334 & -0.448 & 0.027 & 0.627 & 0.87 & 0.326 & 0.104 & -0.199 & -0.291 & -0.42 \\
\hline DOC & Zab-szék & 2014 & -0.515 & -0.563 & -0.349 & 0.093 & 0.673 & 0.951 & 0.62 & 0.125 & -0.164 & -0.401 & -0.344 \\
\hline \multicolumn{14}{|l|}{ FI } \\
\hline CDOM & Sósér & 2017 & 0.344 & 0.114 & 0.314 & -0.029 & -0.115 & -0.297 & -0.413 & -0.175 & -0.017 & -0.04 & 0.158 \\
\hline CDOM & Zab-szék & 2017 & 0.143 & -0.598 & -0.143 & 0.296 & 0.028 & 0.207 & 0.303 & -0.211 & -0.344 & 0.188 & -0.104 \\
\hline DOC & Sósér & 2017 & 0.176 & 0.235 & 0.578 & 0.132 & -0.538 & -0.568 & -0.175 & -0.197 & 0.163 & 0.32 & 0.181 \\
\hline \multicolumn{14}{|l|}{ FRESH } \\
\hline CDOM & Sósér & 2017 & -0.508 & -0.513 & -0.159 & 0.079 & 0.144 & 0.181 & 0.377 & 0.373 & 0.159 & -0.132 & -0.218 \\
\hline CDOM & Zab-szék & 2017 & -0.092 & 0.208 & 0.207 & -0.169 & 0.081 & -0.02 & -0.468 & -0.225 & 0.387 & -0.077 & 0.071 \\
\hline DOC & Sósér & 2017 & -0.164 & -0.396 & -0.617 & -0.275 & 0.365 & 0.89 & 0.624 & -0.027 & -0.387 & -0.356 & -0.059 \\
\hline \multicolumn{14}{|l|}{ HIX } \\
\hline $\mathrm{CDOM}$ & Sósér & 2017 & 0.079 & -0.123 & -0.529 & -0.389 & -0.575 & -0.225 & 0.038 & 0.103 & 0.21 & 0.349 & 0.16 \\
\hline CDOM & Zab-szék & 2017 & 0.284 & 0.155 & -0.44 & 0.244 & 0.067 & -0.362 & 0.4 & 0.042 & -0.578 & 0.058 & 0.09 \\
\hline DOC & Sósér & 2017 & 0.153 & -0.039 & -0.661 & -0.609 & -0.201 & -0.125 & 0.103 & 0.454 & 0.274 & 0.173 & -0.055 \\
\hline
\end{tabular}


Fig. S1. Temperature and precipitation anomalies before and during the sampling periods of the seasonal analysis as six-months mean of difference from mean monthly average measured between 1981-2010. (a) Temperature and (b) precipitation. Based on data from Hungarian Meteorological Service (OMSz).

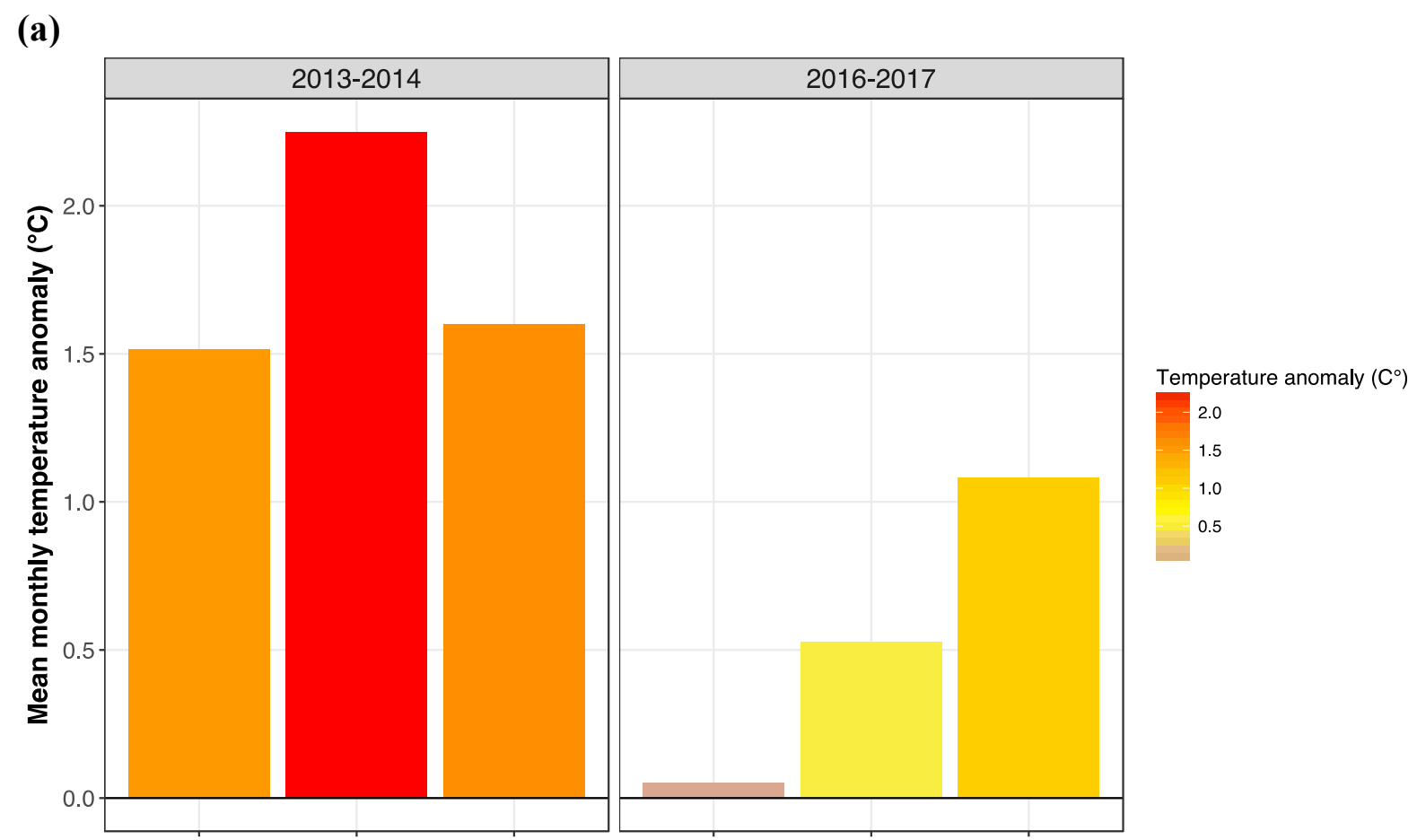

(b)

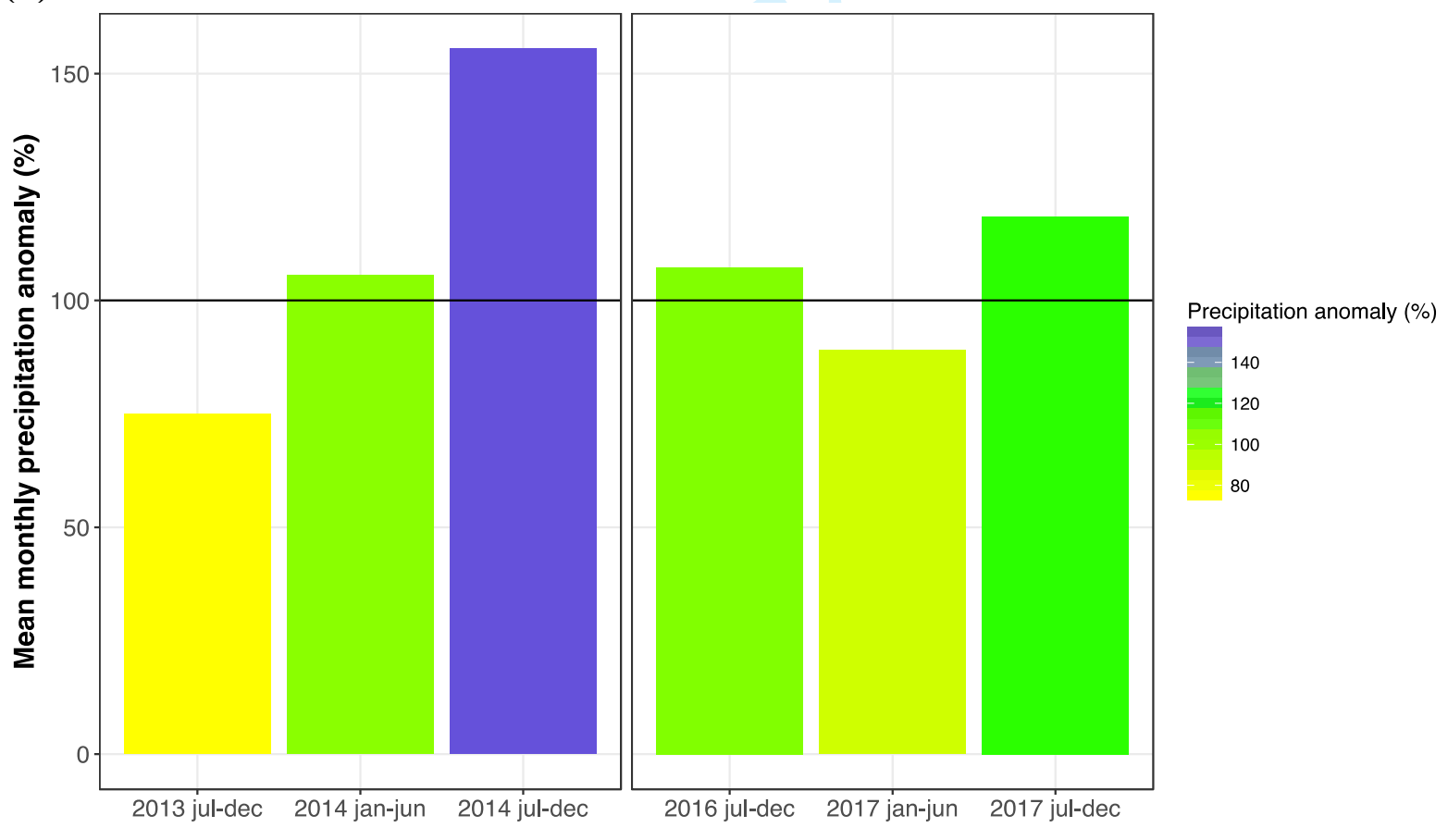




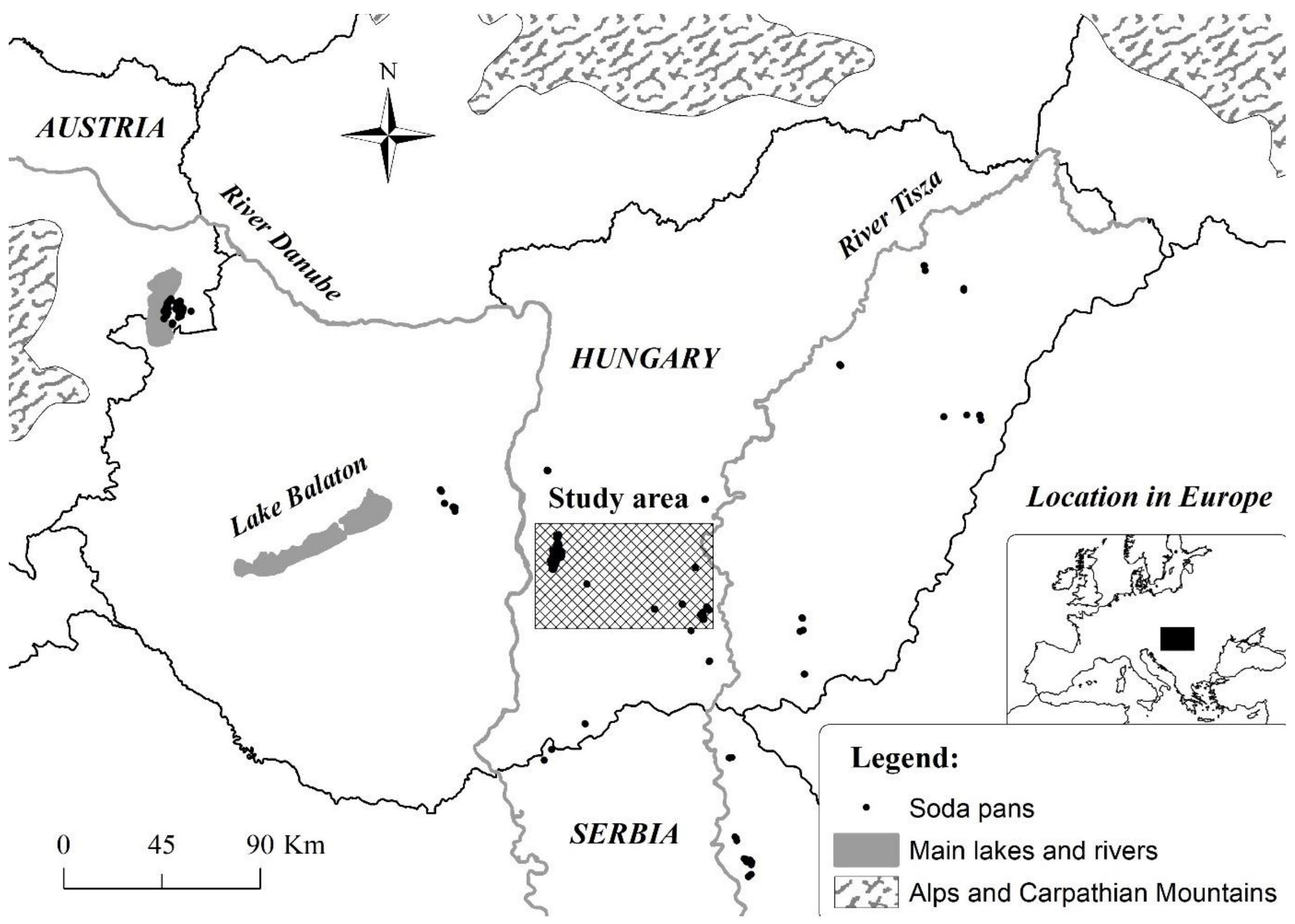


(a)

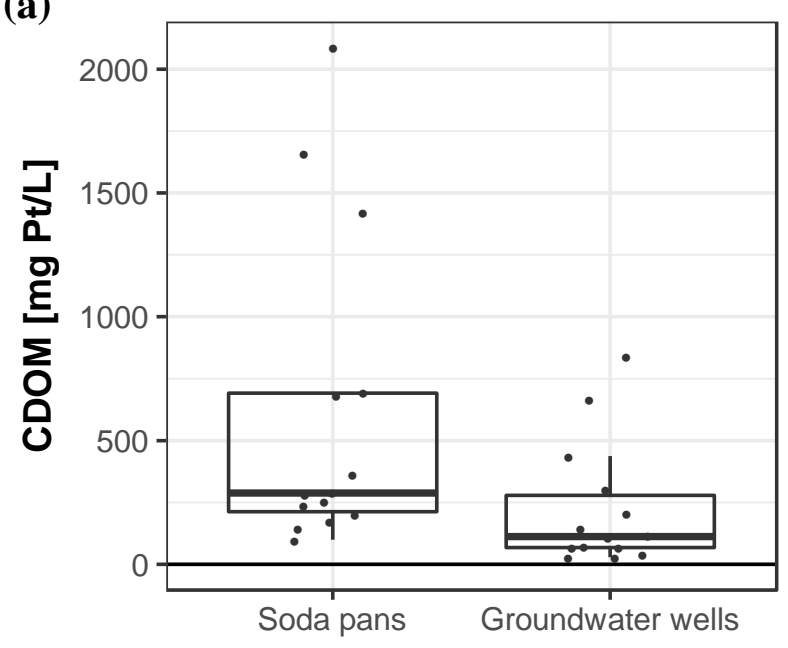

(c)

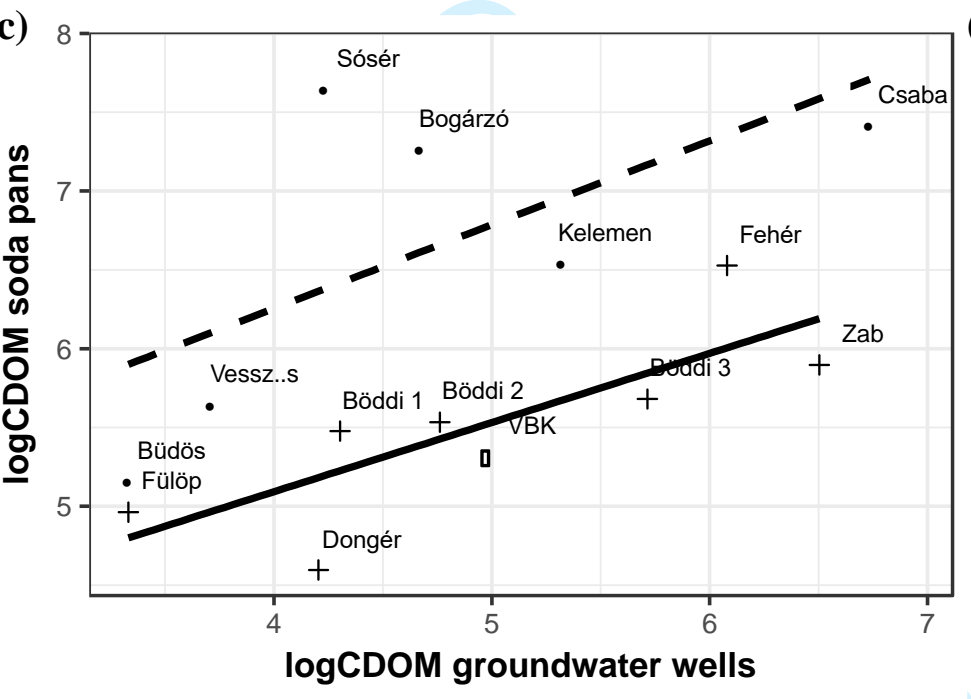

(b)

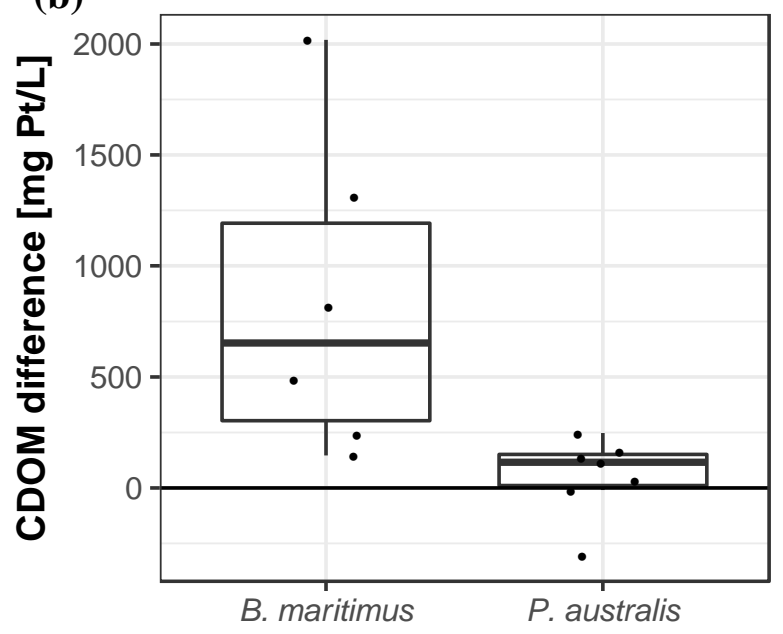

(d)

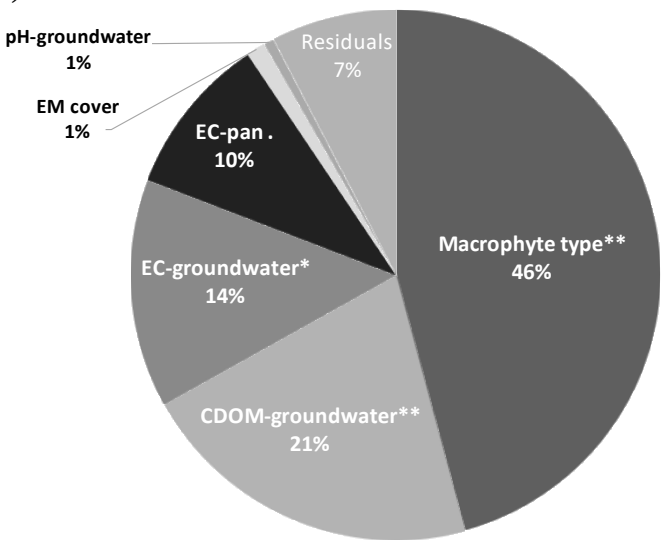

Variance explained 
(a)

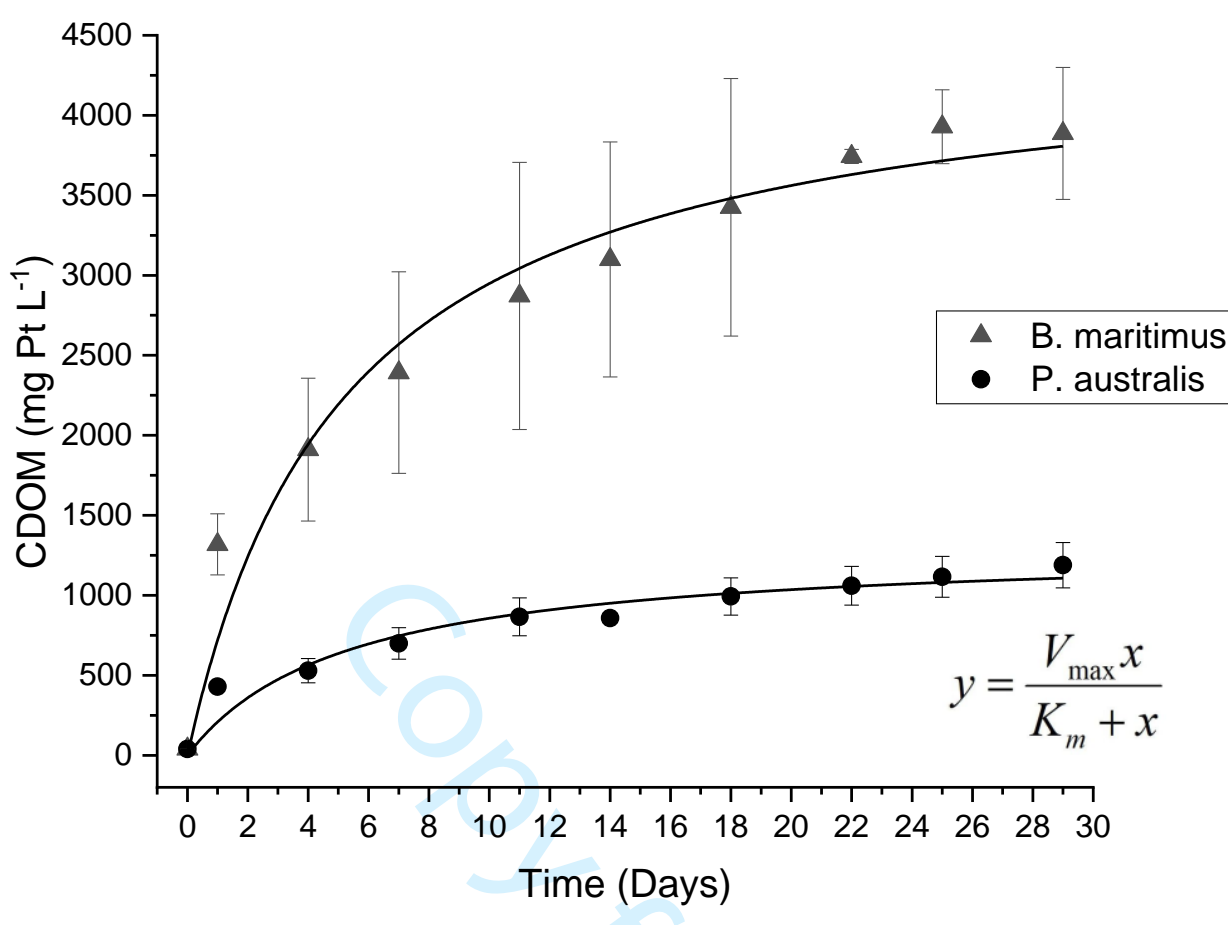

(b)

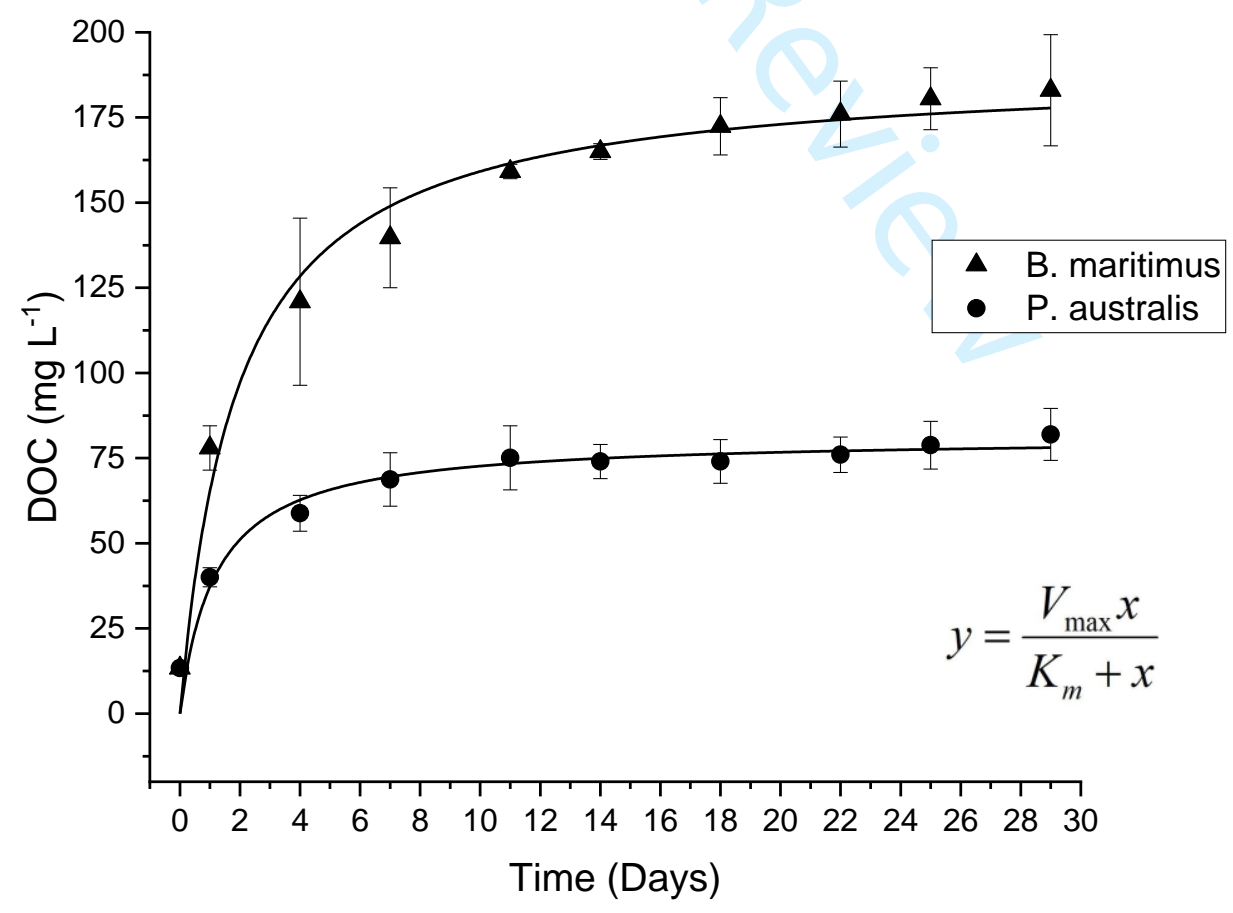


(c)

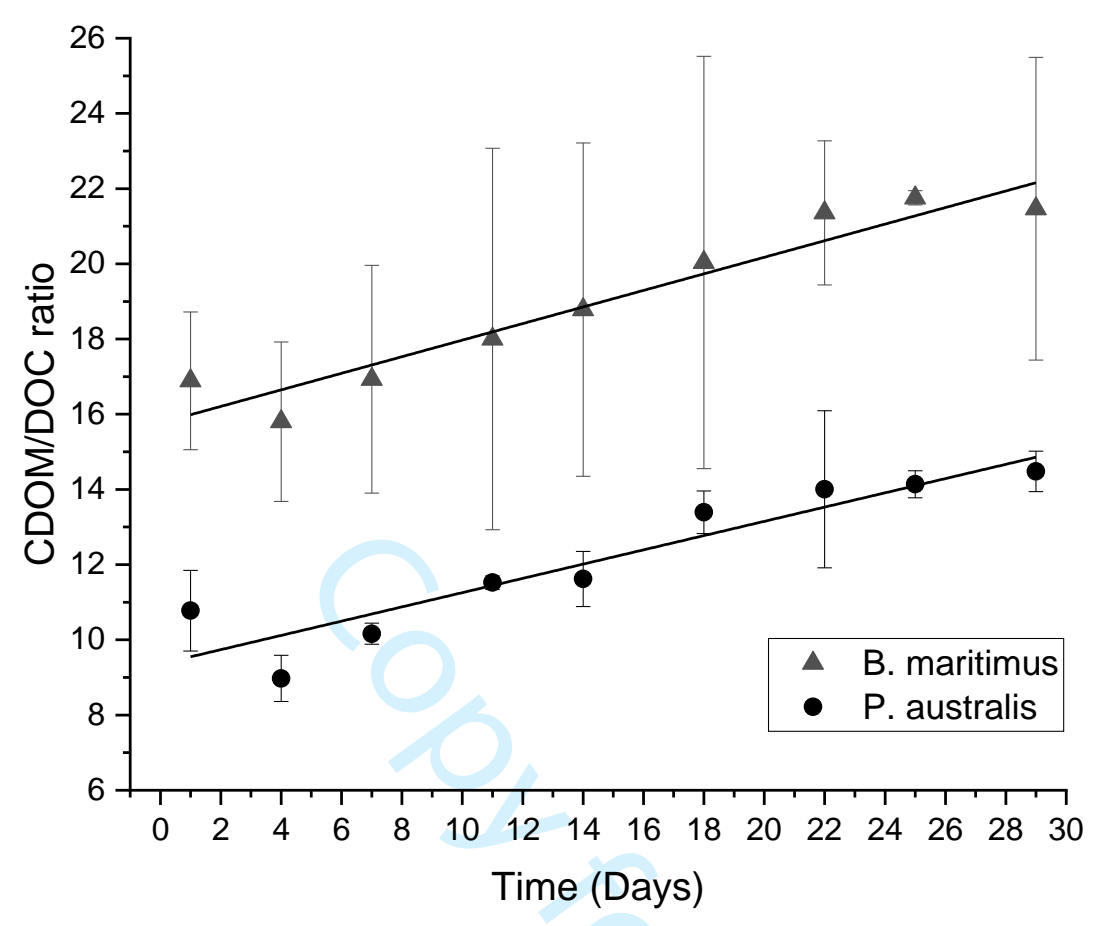

30

31

32 

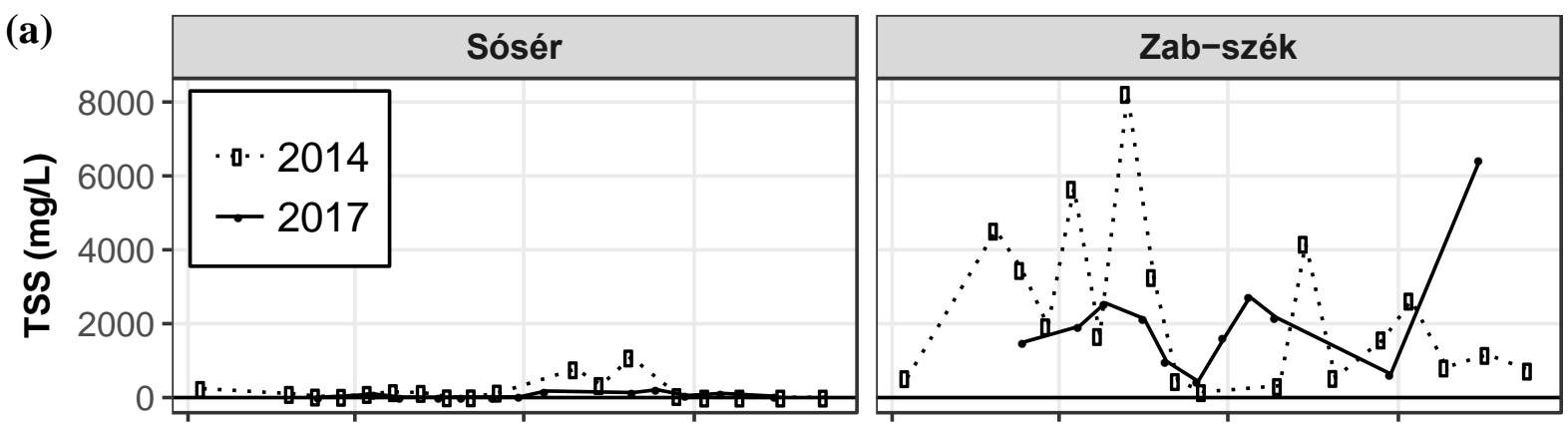

(b)
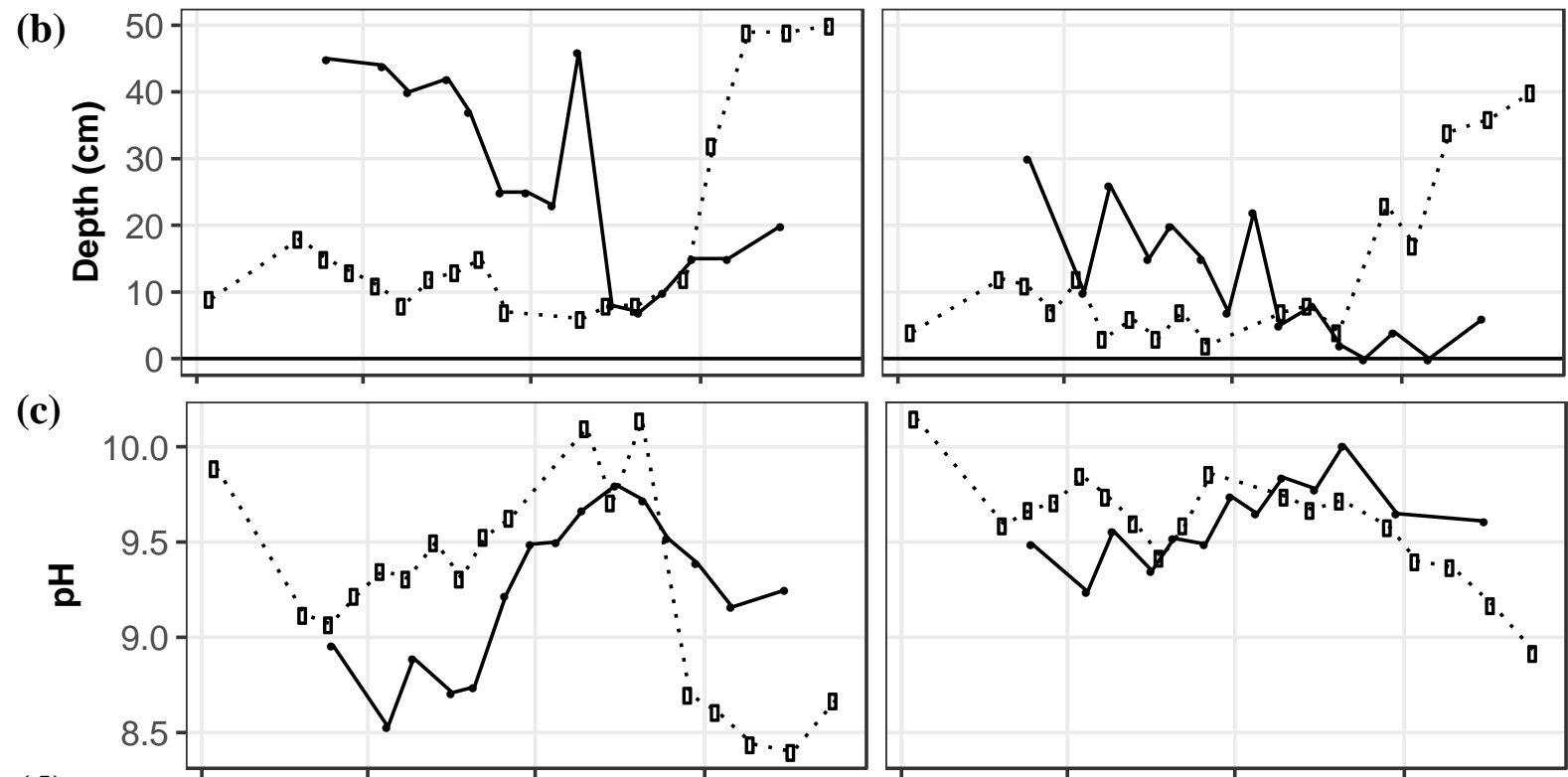

(d)
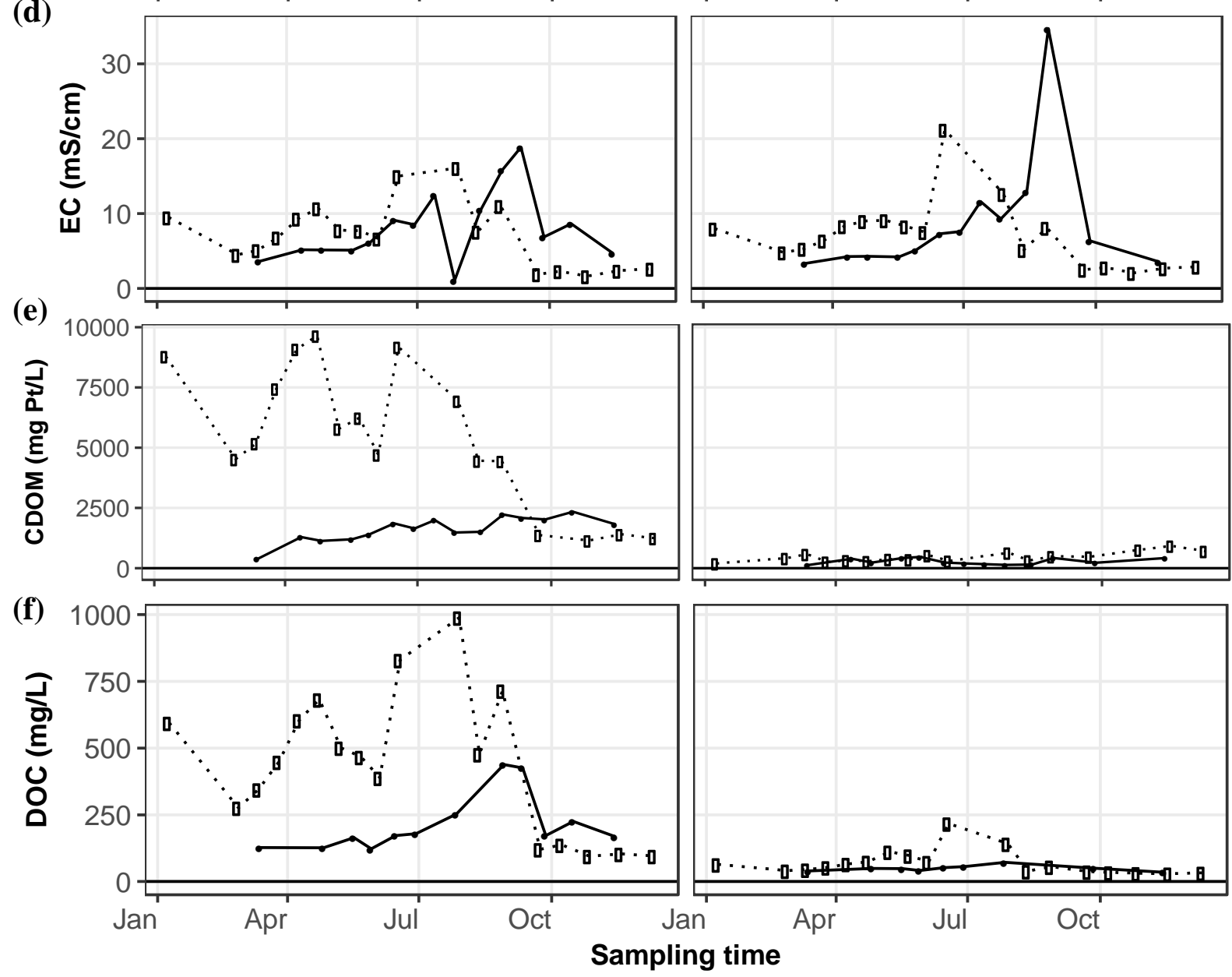


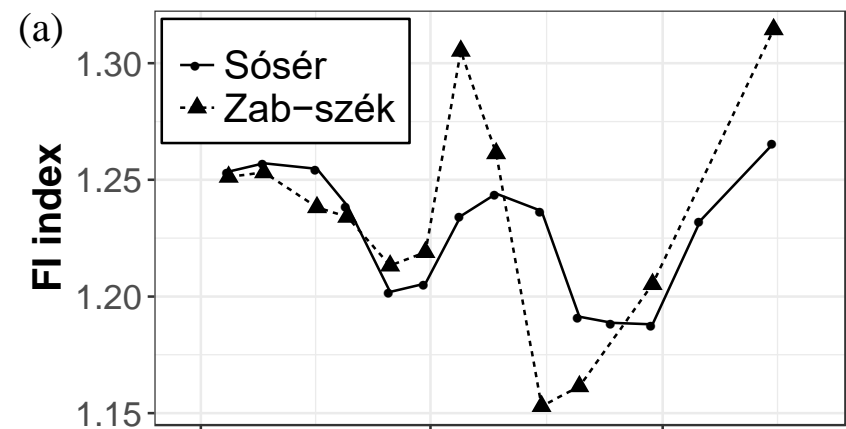

(b) 13 14 15 16 17 18 19 20 21 22 23 24

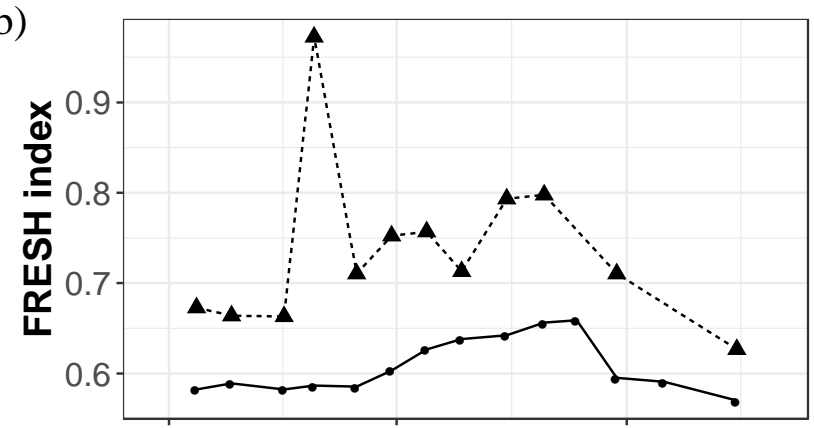

(c)

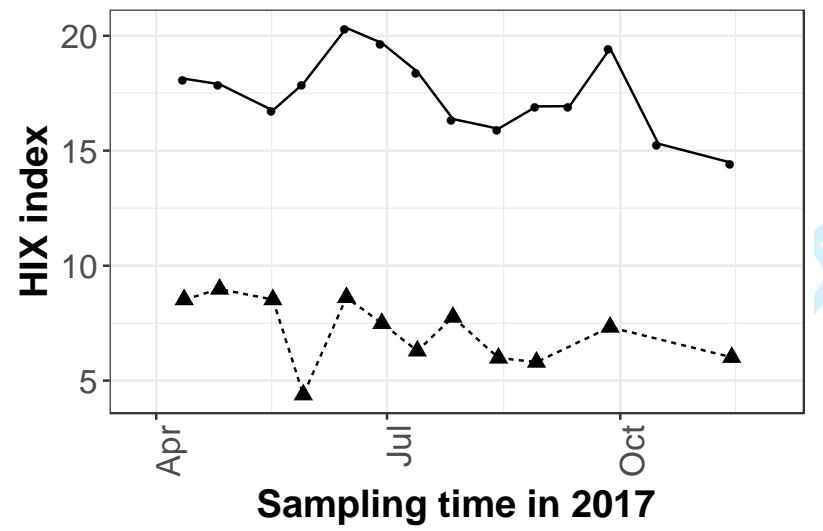

